\title{
Critical Revision and Development Perspectives of Herbicide Residues Analysis in Agro Ecosystems
}

\author{
Verónica Cesio ${ }^{1}$, Lucía Pareja ${ }^{1}$, Silvina Niell ${ }^{1}$, Lucia Geis Asteggiante ${ }^{1}$, \\ Bernardo Böcking2, Claudio García33, Grisel Fernández", \\ Amadeo R. Fernández-Alba ${ }^{5}$ and Horacio Heinzen ${ }^{1}$ \\ ${ }^{1}$ Farmacognosia y Productos Naturales, Facultad de Química UDELAR \\ General Flores 2124, Montevideo 11800, \\ ${ }^{2}$ Donistar S.C, Col. Rubio, Salto, \\ ${ }^{3}$ INIA Las Brujas, Las Brujas, Canelones, \\ ${ }^{4}$ Malherbología EEMAC, Facultad de Agronomía, UDELAR Km366 Ruta 3 Paysandú, \\ ${ }^{5}$ Grupo de Investigación de Laboratorio de Residuos de Plaguicidas, Almería, Universidad \\ de Almería, Cañada de San Urbano s/n, Almeria \\ $1,2,3,4$ Uruguay \\ ${ }^{5}$ Spain
}

\section{Introduction}

Weeds are defined as plants growing in the inadequate place at the inadequate moment. They interfere with the normal crop development and can drop down yields dramatically. Winter cereals show lower losses in average, due to its dense stands and competitive abilities. But, in summer crops, particularly corn that has low densities per area and lower initial growth rates than weeds, very high yield reductions are possible. Rice is very susceptible to weed interferences. There are evidences of production losses from 20 to $96 \%$ (Table 1). Weed control is performed in $100 \%$ of rice cultures either manually, mechanically or chemically. In average, registered losses are around $10 \%$ of production even when weed control has been done. Weed control cost is around 5\%. Consequently, the global cost of this factor is around $15 \%$ of production. In sum, this $15 \%$ is the negative impact weeds have in agricultural and food production.

To control losses in the crop production and as support of the new agronomical techniques for intensive cropping, like no tillage or direct sewing techniques, weed chemical control has been adopted as a usual technique to improve yields.

\section{Herbicide application}

Herbicide application timing depends on various factors such as class of herbicide, weed species aiming to control, mechanic labor, climate, conditions and soil type. This latter factor is very important, particularly soil preparation, previous and present vegetation, humidity content on soil surface and temperature that makes probable a quick weed germination. A 


\begin{tabular}{|c|c|c|c|}
\hline Crop & $\begin{array}{c}\text { \% Production } \\
\text { Decrease }\end{array}$ & Cause & Reference \\
\hline Rice & $20-30$ & $\begin{array}{c}\text { Competition, inadequate } \\
\text { weed control. (Brazil) }\end{array}$ & (Harri, L., 1994) \\
\hline Rice & $\begin{array}{c}25\left(11 \mathrm{pl} / \mathrm{m}^{2}\right) \\
49\left(54 \mathrm{pl} / \mathrm{m}^{2}\right) \\
79\left(269 \mathrm{pl} / \mathrm{m}^{2}\right)\end{array}$ & Echinocloa colonum & (Smith, R. J., 1968) \\
\hline Rice & 40 & $\begin{array}{c}\text { Competition, weed control } 45 \\
\text { d post crop emergence. }\end{array}$ & $\begin{array}{c}\text { (Chebatarrof N., } \\
\text { 2007) }\end{array}$ \\
\hline Corn & $10-15$ & Weed resistant to control & $\begin{array}{c}\text { (Cepeda, S. et al., } \\
\text { 1995) }\end{array}$ \\
\hline Corn & $\begin{array}{c}27-40 \\
97 \text { (if the weed is } \\
\text { Sorghum halepense or } \\
\text { Cynodon dactylon })\end{array}$ & No weed control at all & (Rossi, A. et al., 1996) \\
\hline
\end{tabular}

Table 1. Losses caused by weeds in rice and corn.

general concept is that the herbicide should be applied when the crop has the maximum resistance and weeds are in the most susceptible period (Genta and Villamil, 1992). Herbicide application at pre-emergence stage is closely related with the culture labors of the soil. Once the crop has been sewed, herbicide application is related with crop development and how infested are the present weeds.

\subsection{Preplant treatment}

In rice crops, an herbicide application (i.e. glyphosate) is usually applied in autumn to control existent weeds when machinery labor is needed. This is a non selective treatment and it is done in order to prepare the surface for future work such as levees for irrigation. Probability of weed germination increases with earthwork, favorable conditions of humidity and crop absence.

After land planting, due to humidity conditions of soil in autumn and winter, often great amounts of weeds appear and a herbicide is applied to control them (i.e. glyphosate).

\subsection{Preemergence treatment}

This treatment is done after sowing but before weed emergence. The control consists in combating the seeds that could be in the first soil layer or seeds that have recently germinated when a good control can be achieved.

The main advantage of pre-emergence and preplant treatments is eliminating weed competition in the initial steps of crop development. In general, these treatments are safer and more consistent than post-emergence ones because in crops that irrigation is needed or when it has rained it is difficult to apply the product or hoe. Some disadvantages are that perennial weeds are hard to control and the effectiveness of the products depends on the kind of soil (organic matter content and $\mathrm{pH}$ ). Also these products require to be mobilized by water in soil, so they are not effective under drought conditions.

\subsection{Postemergence treatment}

Selective products must be used in order to eliminate weeds without damaging the crop. The class of weed that can be controlled depends on the tolerance of the crop to the 
herbicide. The risk of damaging the crop is high; temperature is one of the factors that affects the most the effectiveness and volatilization of many post-emergent herbicides, like clomazone. In general when they are applied weeds have already born. An effective weed control is sometimes difficult to achieve because there are many factors that must be taken into account (right climatic conditions, doses, soil humidity level, etc.)

Herbicides are the most employed agrochemicals in agriculture nowadays. Pre or post emergence, root or leaf absorbed, they are applied in huge amounts to hamper weed development worldwide. There are many possible molecular targets to exert the herbicidal action and therefore, herbicides are the vastest group of agrochemicals as there are 53 different chemical families of weed controllers. The most representative herbicide chemical classes are listed in Table 2.

\begin{tabular}{|c|c|c|c|}
\hline $\begin{array}{c}\text { GROUP OF } \\
\text { HERBICIDES }\end{array}$ & EXAMPLES & MODE OF ACTION & $\begin{array}{l}\text { PERSISTANCE IN } \\
\text { SOIL (DT50)* }\end{array}$ \\
\hline \multirow{2}{*}{ Amide } & Florasulam & $\begin{array}{c}\text { Branched chain amino acid } \\
\text { synthesis (AHAS or ALS) inhibitors }\end{array}$ & $2-18 d$ \\
\hline & Propanil & $\begin{array}{l}\text { Photosynthetic electron transport } \\
\text { inhibitor }\end{array}$ & $\mathrm{N} / \mathrm{A}$ \\
\hline \multirow{3}{*}{ Aromatic Acid } & $\begin{array}{c}\text { Dicamba } \\
\text { Quinclorac }\end{array}$ & Auxin growth regulator & $\begin{array}{l}14 \mathrm{~d} \\
\mathrm{~N} / \mathrm{A}\end{array}$ \\
\hline & $\begin{array}{l}\text { Bispyribac- } \\
\text { sodium }\end{array}$ & $\begin{array}{c}\text { Branched chain amino acid } \\
\text { synthesis (AHAS or ALS) inhibitors }\end{array}$ & $<10 \mathrm{~d}$ \\
\hline & $\begin{array}{c}\text { Aminopyralid } \\
\text { Picloram } \\
\end{array}$ & Auxin growth regulator & $\begin{array}{c}8-35 d \\
30-90 d \\
\end{array}$ \\
\hline Bipyridiles & Paraquat & Promotes autoxidation & \\
\hline Dinitroaniline & Pendimethalin & Microtubule assembly inhibition & $3-4 \mathrm{mo}$ \\
\hline Diphenyl Ether & Oxyfluorfen & $\begin{array}{c}\text { Protoporphyrinogen oxidase } \\
\text { inhibitor }\end{array}$ & $5-55 d$ \\
\hline Imidazolinone & Imazapyr & $\begin{array}{l}\text { Branched chain fatty acid } \\
\text { biosynthesis inhibitors }\end{array}$ & $30-150 \mathrm{~d}$ \\
\hline organphosphate & Glyphosate & $\begin{array}{l}\text { Inhibits 5-enolpyruvylshikimate-3- } \\
\text { phosphate synthase. }\end{array}$ & $1-130 d$ \\
\hline $\begin{array}{l}\text { Oxazole } \\
\text { Herbicides }\end{array}$ & Topramezone & $\begin{array}{l}\text { p-Hydroxyphenyl pyruvate } \\
\text { dioxygenase inhibitor }\end{array}$ & $9-81 d$ \\
\hline \multirow[t]{2}{*}{$\begin{array}{l}\text { Phenoxy } \\
\text { Herbicides }\end{array}$} & $\begin{array}{c}\text { MCPA } \\
\text { 2,4-D } \\
\text { Mecoprop-p } \\
\text { Dichlorprop-P } \\
\text { 2,4-DB } \\
\end{array}$ & Auxin growth regulator & $\begin{array}{c}<7 d \\
<7 d \\
3-13 d \\
<7 d\end{array}$ \\
\hline & $\begin{array}{c}\text { Fenoxaprop-P- } \\
\text { ethyl } \\
\text { Cyhalofop- } \\
\text { butyl } \\
\text { Diclofop- } \\
\text { methyl }\end{array}$ & Lipid biosynthesis inhibitors & $\begin{array}{l}1-10 d \\
2-10 h \\
1-57 d\end{array}$ \\
\hline
\end{tabular}




\begin{tabular}{|c|c|c|c|}
\hline $\begin{array}{l}\text { GROUP OF } \\
\text { HERBICIDES }\end{array}$ & EXAMPLES & MODE OF ACTION & $\begin{array}{l}\text { PERSISTANCE IN } \\
\text { SOIL (DT50)* }\end{array}$ \\
\hline $\begin{array}{l}\text { Pyrazole } \\
\text { Herbicides }\end{array}$ & Pinoxaden & Lipid biosynthesis inhibitors & $<1 d$ \\
\hline \multirow{2}{*}{$\begin{array}{l}\text { Pyridine } \\
\text { Herbicides }\end{array}$} & $\begin{array}{l}\text { Fluroxypyr } \\
\text { Diflufenican }\end{array}$ & Auxin growth regulator & $\begin{array}{l}5-9 d \\
36,3 d\end{array}$ \\
\hline & Pyroxsulam & $\begin{array}{c}\text { Branched chain amino acid } \\
\text { synthesis (AHAS or ALS) inhibitors }\end{array}$ & $<15 d$ \\
\hline $\begin{array}{c}\text { Triazine } \\
\text { Herbicides } \\
\end{array}$ & Atrazine & $\begin{array}{c}\text { Photosynthetic electron transport } \\
\text { inhibitor }\end{array}$ & $16-77 d$ \\
\hline \multirow[t]{2}{*}{$\begin{array}{l}\text { Triazolone } \\
\text { Herbicides }\end{array}$} & $\begin{array}{l}\text { Carfentrazone- } \\
\text { ethyl }\end{array}$ & $\begin{array}{c}\text { Branched chain amino acid } \\
\text { synthesis (AHAS or ALS) inhibitors }\end{array}$ & $2,5-4 d$ \\
\hline & $\begin{array}{c}\text { Propoxycarbaz } \\
\text { one-sodium } \\
\text { Flucarbazone- } \\
\text { sodium } \\
\end{array}$ & $\begin{array}{c}\text { Branched chain amino acid } \\
\text { synthesis (AHAS or ALS) inhibitors }\end{array}$ & $\begin{array}{c}12-56 d \\
17 d\end{array}$ \\
\hline $\begin{array}{l}\text { Triazolopyrimid } \\
\text { ine Herbicides }\end{array}$ & Flumetsulam & $\begin{array}{c}\text { Branched chain amino acid } \\
\text { synthesis (AHAS or ALS) inhibitors }\end{array}$ & $\leq 1 \mathrm{mo}$ \\
\hline Urea & Isoproturon & $\begin{array}{l}\text { Photosynthetic electron transport } \\
\text { inhibitor }\end{array}$ & $6-28 \mathrm{~d}$ \\
\hline Sulphonylureas & $\begin{array}{c}\text { Amidosulfuron } \\
\text { Bensulfuron- } \\
\text { methyl } \\
\text { Flupyrsulfuron } \\
\text {-methyl- } \\
\text { sodium } \\
\text { Iodosulfuron- } \\
\text { methyl-sodium } \\
\text { Metsulfuron- } \\
\text { methyl } \\
\text { Pyrazosulfuron } \\
\text {-ethyl } \\
\text { Sulfosulfuron } \\
\text { Thifensulfuron- } \\
\text { methyl } \\
\text { Triasulfuron } \\
\text { Tribenuron- } \\
\text { methyl } \\
\text { Foramsulfuron } \\
\text { Chlorsulfuron }\end{array}$ & $\begin{array}{c}\text { Branched chain amino acid } \\
\text { synthesis (AHAS or ALS) inhibitors }\end{array}$ & $\begin{array}{c}3-29 \mathrm{~d} \\
14 \mathrm{~d} \\
1-5 \mathrm{~d} \\
52 \mathrm{~d} \\
10-21 \mathrm{~d} \\
11-47 \mathrm{~d} \\
1-7 \mathrm{~d} \\
19 \mathrm{~d} \\
3,5-5,1 \mathrm{~d} \\
1,5-9,4 \mathrm{~d} \\
4-6 \mathrm{w}\end{array}$ \\
\hline $\begin{array}{l}\text { Unclassified } \\
\text { Herbicides }\end{array}$ & $\begin{array}{l}\text { Bentazone } \\
\text { Clomazone }\end{array}$ & $\begin{array}{c}\text { Photosynthesis inhibition } \\
\text { Carotenoid biosythesis inhibition }\end{array}$ & $\begin{array}{c}12 \mathrm{~d} \\
30-135 \mathrm{~d}\end{array}$ \\
\hline
\end{tabular}

* Degradation half-life: $\mathrm{d}$ - days, $\mathrm{w}$ - weeks, mo - months; N/A: not available

Table 2. Most representative chemical families of herbicides 


\section{Economical aspects}

Higher land, use intensity and short crop rotations (or sometimes no rotation at all) plus no tillage technology leads to an increase in the usage and dependency of agrochemicals. Pests and weeds problem increases when land use is more and more intensive. Weeds negatively affect grain production and quality, which declines prices. Also, harvesting becomes complex and more expensive. Resources competition and allelopathy interferences, like light, water, $\mathrm{CO}_{2}$ and soil nutrient competition provokes important or complete economic losses. On top of that, weeds are pest hosts and disseminate crop infections.

\subsection{Herbicides trade and usage}

In 2009, herbicides represented $75 \%$ of agrochemical imports in $\mathrm{kg}$ and $59.5 \%$ in U\$S/CIF, showing they continue to be the most employed agrochemicals in Uruguay. As shown in Figure 1, herbicides prevail in agrochemicals world trade. In Uruguay, this tendency is even stronger when compared to Brazil although Argentina has bigger differences than Uruguay (63\%, 20\% and $9 \%$ herbicides, insecticides and fungicides respectively) (casafe website).

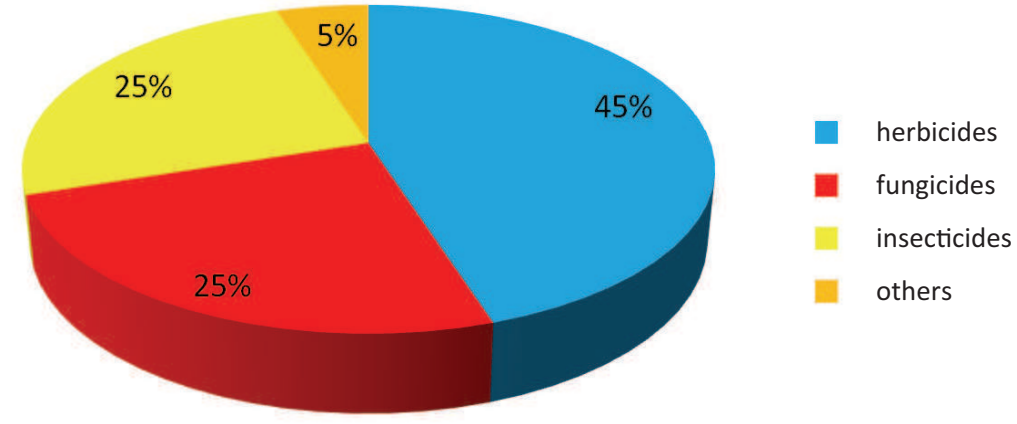

Fig. 1. Agrochemicals world trade (Rana, S. AGROW, 2010)

Herbicides show the higher relative increase when compared to fungicides and insecticides between 2003 and 2009. Glyphosate accounts for $57 \%$ of herbicides total.

As stated above, rice production needs intensive herbicide use. From 141.500 ha of rice crop analyzed and registered, the $98 \%$ (138.000 ha) required the appliance of herbicides with repeated control treatments in about the $10 \%$ of the treated area (Molina et al., 2010). Fields never used for rice crops were included in the area under treatment, along with pasture, which despite of doing the adequate rotation, showed the presence of weeds in quantities above the threshold for economic damage requiring control with herbicides. The active ingredients used are shown in Table 3.

As shown in Table 4, the most common herbicide treatment is atrazine for corn and sorghum in mixture with a chloroacetamide in pre-emergence. Post-emergent options such as imidazolinones (Imazethapyr + imazapyr or imazapic + imazapyr) are preferred for corn with zero tillage because of straw interactions with pre-emergent herbicides. However, at present there are only limited numbers of cultivars with tolerance for these herbicides and so very few hectares had been treated with imidazolinones in the last years. Other postemergent options as growth regulators herbicides, the mixture of iodosulfuron plus foramsulfuron or topramezone had not been extensively adopted. They are more expensive 


\begin{tabular}{|c|c|c|}
\hline Products or mixtures applied & $\begin{array}{l}\text { Area of appliance } \\
\text { (ha) } \mathrm{T}\end{array}$ & $\%$ \\
\hline Quinclorac+Clomazone+Propanil & 45660 & 30 \\
\hline Clomazone+Glyphosate & 18198 & 12 \\
\hline Clomazone+Quinclorac & 8975 & 6 \\
\hline Bispyribac-sodium+Clomazone & 7521 & 5 \\
\hline Quinclorac+Clomazone+Propanil+Pyrazosulfuron-ethyl & 6964 & 5 \\
\hline Bispyribac-sodium & 5342 & 4 \\
\hline Clomazone+Propanil & 4977 & 3 \\
\hline Others & 52667 & 35 \\
\hline Total & 150.304 & 100 \\
\hline Clomazone alone or as mixture & 118017 & 79 \\
\hline Quinclorac alone or as mixture & 77683 & 52 \\
\hline
\end{tabular}

Table 3. Active ingredients used in rice production in Uruguay

\begin{tabular}{|c|c|c|}
\hline Crop & Herbicide & Application \\
\hline \multirow{5}{*}{ Corn } & Atrazine & \multirow{2}{*}{ Pre-emergence } \\
\hline & chloroacetamides & \\
\hline & Iodosulfuron + foramsulfuron & \multirow{3}{*}{ Post-emergence } \\
\hline & Topramezone & \\
\hline & imidazolinonas & \\
\hline \multirow{2}{*}{ Sorghum } & Atrazine & \multirow{2}{*}{ Pre-emergence } \\
\hline & chloroacetamide & \\
\hline \multirow{3}{*}{ Soybean } & Glyphosate & Post-emergence \\
\hline & Imazethapyr & pre/ post-emergence \\
\hline & Diclosulam & pre/ post-emergence \\
\hline \multirow{9}{*}{$\begin{array}{c}\text { Wheat } \\
\text { and } \\
\text { Barley }\end{array}$} & Pyroxsulam (only wheat) & Post-emergence \\
\hline & Flucarbazone (only wheat) & Post-emergence \\
\hline & Iodosulfuron & Post-emergence \\
\hline & Pinoxaden & Post-emergence \\
\hline & Diclofop-methyl & Post-emergence \\
\hline & Fenoxaprop & Post-emergence \\
\hline & Metsulfuron & Post-emergence \\
\hline & Metsulfuron + Chlorsulfuron & Post-emergence \\
\hline & $\begin{array}{c}\text { growth regulators }(2,4 \mathrm{D} \text { amine, } \\
\text { Dicamba, Picloram) }\end{array}$ & Post-emergence \\
\hline \multirow{2}{*}{$\begin{array}{l}\text { Artificial } \\
\text { pastures }\end{array}$} & Flumetsulam & Post-emergence \\
\hline & 2,4 DB ester & Post-emergence \\
\hline
\end{tabular}

Table 4. Herbicides most commonly used in extensive crops and artificial pastures in Uruguay 
and their performances had not demonstrated clear advantages compared with the classic pre-emergent mixture of atrazine+chloroacetamides except in specific weed situations.

There are potential risks of persistence with this treatment including atrazine. In production systems alternating crops and pastures where corn or sorghum crops grown for silage are followed by pastures with legumes and grasses or by oats, plant-back period may resulted insufficient for atrazine dissipation and damage occurrence.

Soybean area, entirely GMO planted crop, is basically treated with glyphosate. Nevertheless, It has been registered an increased trend to complement glyphosate with residuals herbicides like imazethapyr or diclosulam looking to reduce number of glyphosate applications and to broad control spectrum. There is an increasing movement of the big breeders companies towards the inclusion in the new varieties, some resistant genes against particular herbicide mode of action. Following the trend initiated by the glyphosate resistant RR soybean, crop varieties resistant to imidazolinones (rice, corn) glufosinate (rice) sulphonylureas (sunflower) has been registered. The use of these varieties will boost the use of the specific herbicides and therefore new challenges on environmental risk assessment on soil, water and food can be foreseen.

Herbicide options for winter cereals, wheat and barley are various and especially in case of weed grasses. Number and total use of graminicides has increased markedly. The most used are pinoxaden, pyroxsulam, iodosulfuron, flucarbazone, diclofop methyl and fenoxaprop. The use of these herbicides has five-folded since 2006 even though winter crop area has just doubled during this period, in association with the widespread infestations of grasses in agriculture lands.

Other herbicides widely used for winter cereals are the sulphonylureas, metsulfuron and chlorsulfuron as they have a broad spectrum of weed control, may be sprayed early and have important residual effects, so satisfactory controls are reached in species with continued emergences fluxes as commonly happens with winter weed species in our country. However, application of these herbicides implies a risk of persistence as commonly happens when used in fallow seed-bed preparation without considering the plant-back guidelines for crop rotation. See for example Bradford et al, 2008. Its low cost and wide spectrum makes them highly attractive for use in mixtures with glyphosate in fallow seedbed preparation for summer and winter crops, being frequent situations of persistence problems.

These problems, occasional phytotoxicity effects and risk of resistance, have been promoting a return to traditional growth regulators treatments such as 2,4-D amine in mixtures with dicamba, picloram, etc. or new options like aminopyralid. Also in artificial pastures use of herbicides is incremental. The most common treatment in this areas is flumetsulam alone or in mixtures with 2,4-DB ester.

In this introduction it is shown that herbicide usage has been integrated systematically in cropping systems, that there is no universal procedure to perform weed control and different herbicidal combinations are employed in different stages of crop production. Although some herbicides are used in very low doses, and many of them are designed to inhibit specific pathways of plant metabolism, their interference with metabolic pathways of other organisms is a growing concern. Some herbicides are persistent between two cropping systems and can affect the new crop, notably atrazine and the sulphonylureas. Therefore, for public health reasons and systems sustainability the knowledge of the level of remaining herbicide residues has to be ascertained. In the past, sometimes the low dosage of these compounds hampered a clear determination of their residual level in the different 
environmental compartments. Nowadays the development of new sample treatment procedures either instrumental, like ASE or MASE or not, like QuEChERS, coupled to hyphenated MS/MS techniques allow the detection of very low levels of these compounds in different matrices. The present chapter aims to present some characteristics of herbicide analysis, to explore the reasons why many currently used herbicides have not been included in the most common Multi Residue Methods developed and to give some insights on the different aspects that should be considered when trying to include herbicides in a multiresidue method.

\section{Herbicide residues analysis}

The analysis of herbicides has been confined to single residue methods, or class herbicide residue analysis (phenoxyacid herbicides, imidazolinones, sulphonylureas, triazines). Nevertheless, the real situation is that cationic, anionic, basic or acid herbicides together with fungicides and insecticides can be applied successively over a crop looking for different protecting effects. They accumulate in the crop and the environment and when evaluating their presence in the different compartments they can seldom be determined in one single analytical procedure. To define the scope of a multirresidue method that will allow the simultaneous determination of many herbicides belonging to different chemical classes, the physicochemical properties of the agrochemicals must be carefully evaluated. The physicochemical properties of some representative herbicides are listed in Table 5.

\begin{tabular}{|c|c|c|c|c|c|}
\hline Herbicide & Koc & $\log$ Kow & $\underset{20-25^{\circ} \mathrm{C}}{\log \mathrm{Ws}\left(\mathrm{mg} \mathrm{L}^{-1}\right)}$ & $\begin{array}{c}\mathrm{H} \\
\left(\mathrm{Pa} \mathrm{m}^{3} \mathrm{~mol}^{-1}\right)\end{array}$ & $\begin{array}{c}\text { Vapor } \\
\text { Pressure } \\
(\mathrm{mPa})\end{array}$ \\
\hline $2,4-\mathrm{D}$ & 60 & $2.58-2.83$ & 4.37 & $1.32 \times 10-5$ & $1.86 \times 10-2$ \\
\hline 2,4-DB & - & - & 1.66 & - & - \\
\hline Amidosulfuron & - & 1.63 & 0.95 & $5.34 \times 10-4$ & $2.20 \times 10-2$ \\
\hline Aminopyralid & - & 0.201 & 3.39 & - & $9.52 \times 10-6$ \\
\hline Atrazine & $39-173$ & 2.50 & 1.52 & $1.50 \times 10-4$ & $3.85 \times 10-2$ \\
\hline Bensulfuron-methyl & - & 0.79 & 1.83 & $2.00 \times 10-11$ & $2.80 \times 10-9$ \\
\hline Bentazone & $13.3-176$ & -0.46 & 2.76 & - & $5.4 \times 10-3$ \\
\hline Bispyribac-sodium & - & -1.03 & 4.87 & $3.12 \times 10-11$ & $5.05 \times 10-6$ \\
\hline Carfentrazone-ethyl & $15-35$ & 3.36 & 1.08 & $2.47 \times 10-4$ & $7.2 \times 10-3$ \\
\hline Chlorsulfuron & 40 & -0.99 & 4.50 & $3.50 \times 10-11$ & $3.00 \times 10-6$ \\
\hline Clomazone & $150-526$ & 2.50 & 3.04 & $4.19 \times 10-3$ & 19.2 \\
\hline Cyhalofop-butyl & 5247 & 3.31 & -0.36 & $9.51 \times 10-4$ & $5.30 \times 10-2$ \\
\hline Dicamba & 2 & -1.88 & $>5.40$ & $6.10 \times 10-5$ & 1.67 \\
\hline Dichlorprop-P & - & -0.25 & 2.77 & $2.47 \times 10-5$ & 0.06 \\
\hline Diclofop-methyl & $\begin{array}{l}14000- \\
24400\end{array}$ & 4.58 & -0.10 & $2.19 \times 10-1$ & 0.25 \\
\hline Diflufenican & - & 4.90 & -1.30 & $1.18 \times 10-2$ & $4.25 \times 10-3$ \\
\hline Fenoxaprop-P-ethyl & - & 4.58 & -0.15 & $2.74 \times 10-4$ & $1.80 \times 10-1$ \\
\hline
\end{tabular}




\begin{tabular}{|c|c|c|c|c|c|}
\hline Florasulam & $2-069$ & -1.22 & 3.80 & $4.35 \times 10-7$ & $1.00 \times 10-2$ \\
\hline Flucarbazone-sodium & - & -1.84 & 4.64 & $<1 \times 10-11$ & $<1 \times 10-6$ \\
\hline Flumetsulam & $5-182$ & -0.68 & 1.69 & - & $3.7 \times 10-7$ \\
\hline $\begin{array}{l}\text { Flupyrsulfuron- } \\
\text { methyl-sodium }\end{array}$ & - & 0.10 & 2.78 & $1 \times 10-8$ & $1 \times 10-6$ \\
\hline Fluroxypyr & - & -1.24 & 3.76 & $1.06 \times 10-8$ & $3.78 \times 10-6$ \\
\hline Foramsulfuron & $38-151$ & -0.78 & 3.52 & $5.80 \times 10-12$ & $4.20 \times 10-8$ \\
\hline Glyphosate & - & $<-3.20$ & 4.02 & $<2.10 \times 10-7$ & $1.31 \times 10-2$ \\
\hline Imazapic & - & 0.39 & 3.33 & - & $<1 \times 10-2$ \\
\hline Imazapyr & - & 0.11 & 4.05 & - & $<0.013$ \\
\hline Imazaquin & - & 0.34 & $1.78-2.08$ & $3.70 \times 10-12$ & $<0.013$ \\
\hline $\begin{array}{l}\text { Iodosulfuron-methyl- } \\
\text { sodium }\end{array}$ & $0.80-152$ & -0.70 & 4.40 & $2.29 \times 10-11$ & $6.70 \times 10-6$ \\
\hline Isoproturon & - & 2.50 & 1.81 & $1.46 \times 10-5$ & $3.15 \times 10-3$ \\
\hline MCPA & - & 2.75 & 2.47 & $5.50 \times 10-5$ & $2.30 \times 10-2$ \\
\hline Mecoprop-p & $12-025$ & 0.1004 & 2.94 & $2.18 \times 10-4$ & 1.60 \\
\hline Metsulfuron-methyl & - & 0.018 & 3.45 & $4.50 \times 10-11$ & $3.3 \times 10-7$ \\
\hline Oxyfluorfen & 2891 (sand) & 4.47 & -0.94 & - & 0.0267 \\
\hline Pendimethalin & - & 5.20 & -0.48 & 2.728 & 1.94 \\
\hline Picloram & - & 1.90 & -0.25 & - & $8 \times 10-11$ \\
\hline Pinoxaden & - & 3.20 & 2.30 & - & $2 \times 10-9$ \\
\hline Propanil & $239-800$ & 3.30 & 2.11 & $1.70 \times 10-4$ & 0.02 \\
\hline $\begin{array}{c}\text { Propoxycarbazone- } \\
\text { sodium }\end{array}$ & 28,8 & -1.55 & 4.62 & $<1 \times 10-10$ & $<1 \times 10-5$ \\
\hline Pyrazosulfuron-ethyl & - & 3.16 & 0.99 & - & $4.20 \times 10-5$ \\
\hline Quinclorac & - & -0.74 & -1.19 & - & $<0.01$ \\
\hline Sulfosulfuron & 33 & -0.77 & 3.21 & $8.83 \times 10-9$ & $3.1 \times 10-5$ \\
\hline $\begin{array}{l}\text { Thifensulfuron- } \\
\text { methyl }\end{array}$ & - & 0.02 & 3.35 & $9.70 \times 10-16$ & $1.70 \times 10-5$ \\
\hline Topramezone & - & -1.52 & 2.71 & - & $<1 \times 10-12$ \\
\hline Triasulfuron & - & -0.59 & 2.91 & $<8 \times 10-5$ & $<2 \times 10-3$ \\
\hline Tribenuron-methyl & - & 0.78 & 3.31 & $1.03 \times 10-8$ & $5.20 \times 10-5$ \\
\hline
\end{tabular}

Table 5. Physicochemical and environmental properties of some selected herbicides

As an example, when looking for a procedure that can include the analysis of imidazolinone residues their peculiar $\mathrm{pH}$ behavior has to be considered. The Imidazolinones are amphoteric molecules that can exist in anionic, neutral or cationic states depending upon the $\mathrm{pH}$ of the environment. The $\mathrm{pKa}$ values of imidazolinone herbicides range from 1.9 to 3.9. When the $\mathrm{pH}$ of the extracting solvent is greater than their $\mathrm{pKa}$, these herbicides are usually present mainly in an anionic state as carboxylates. On the other hand, the acidic functional group is completely in a non-ionized state when the $\mathrm{pH}$ is two units lower than the most 
acidic $\mathrm{pKa}$ value. Therefore factors such as $\mathrm{pH}$, organic carbon content, and ionic strength may affect their extractability to perform the analysis. All these factors also affect the fate of the imidazolinone herbicides in the environment which are relatively persistent in soil with half-lives ranging from 30 to 150 days and therefore, may have carryover effects on the rotation system of winter-summer crops. Moreover, it has been reported that the imidazolinone herbicides show high potential for leaching because of their relatively low pKa values (1.9-3.9). (Ramezani et al., 2009)

But not only have these factors operated. The matrix characteristics are crucial for the precision and accuracy of the analysis. Differences in pesticide absorption and recoveries were found when comparing results from contrasting soils (Boivin et al., 2005).

\section{Environmental samples}

The major public health concern on herbicide residues in the environment is due to the fact that many of them have low Koc and relatively low Kow and therefore, can either lixiviate, leach or run off and contaminate ground and surface water. Many herbicides have been identified as endocrine disrupters and they threaten wild life as Atrazine (Barchanska \& Baranowska, 2009). The usual methodology for contaminant analysis in water is the solid phase extraction either off line or on line coupled with the analytical instrument (GC or HPLC). The adsorbed compounds are eluted from the stationary phase with a polar organic solvent and the extract is analyzed directly. This simple procedure allows sample concentration increasing the limit of detection of the method to $\mathrm{ngkg}^{-1}$ level or ppts, fulfilling the requirements of the European legislation on drinking water, where pesticide limits of quantification (LOQs) of $0.025 \mu \mathrm{gL}^{-1}$, four times lower than the maximum allowed $\left(0.1 \mu \mathrm{gL}^{-1}\right)$, are required. To perform the SPE extraction RP C18 silica gel cartridges have been employed, but the most widely extraction phases employed are polymeric styrene, polystyrene divinil-benzene polymers or N-vinylpyrrolidone. These cartridges are commercially available with different brand names. This solid phase has a medium polarity that allows the selective retention of relatively polar compounds. In this way many different herbicides belonging to various chemical families (sulphonylureas, anilides, imidazolinones, phenoxy acids) have been selectively absorbed and quantitatively analyzed. Solid phase microextraction (SPME) is a very attractive analytical technique for herbicide residue analysis in water. Serôdio (Serôdio et al., 2004) analyzed 13 herbicides which are endocrine disruptors performing a micro extraction using a poliacrilate coated sorptive stirring bar for pesticide extraction, performing a back extraction procedure with acetonitrile to recover all analytes with high selectivity. A miscellaneous procedure for the selective analysis of triazine herbicides in water was presented by (Nelson et al., 2004). A portable system based on immunoextraction and reversed-phase HPLC was developed for the field analysis of herbicides in groundwater and surface water. Using inmunotemplates to concentrate atrazine, simazine, and cyanazine and analyzing them through HPLC, a LOQ of a $0.2 \mathrm{mg} \mathrm{L}$ ${ }^{1}$ up to $100 \mathrm{mg} \mathrm{L}^{-1}$ were achieved. This procedure can be applied to the high throughput analysis of water samples as a single determination took less than $8 \mathrm{~min}$. Another type of class analysis of herbicide residues is the use of molecular imprinted polymers to selectively extract sulphonylureas in water (Bastide et al., 2005). The highly selective polymer concentrates the herbicide residues allowing their determination at the sub ppt level.

MIP technique can be coupled to chemiluminscence sensing, taking advantage of the reaction of many sulphonylureas with luminal $+\mathrm{H}_{2} \mathrm{O}_{2}$ as reported by (Xie et al., 2010) reaching detection levels of $1-10 \mathrm{nM} \mathrm{L}^{-1}$ of sulphonylureas in water. MIP methodology with 
its different applications off line, on line or in line has been recently reviewed. Due to the low application doses of herbicides (Table 6) the development of such polymers offers the possibility of sub trace analysis for different herbicide classes. Nevertheless, the improvement of the new LC-MS/MS equipment, allow the detection of many agrochemicals in water, just by filtrating and injecting the sample.

\subsection{Herbicide residue analysis in water}

In the last decades, liquid-liquid extraction (LLE) has been largely replaced by solid phase extraction (SPE). In 2009 Pinxteren et al., compared the performance of SPE and microwave assisted-solvent extraction (MASE or MAE), both in combination with LC-MS/MS, for the analysis of 10 pesticides in water. The main conclusion of the study was that SPE has the potential of larger sensitivity whereas MASE is faster, provides slightly better recoveries, and represents a promising alternative to conventional off-line SPE concerning low to medium polar compounds (Pinxteren et al., 2009)

One of the advantages of SPE compared to other techniques is the variety of sorbents available. As an example, Geiss et al., compared the performance of 21 cartridges packed with different octadecyl silica, polymeric, modified silica, ion exchange and carbon materials for the extraction of highly polar organophosphorus pesticides from water. In this study the polymeric cartridges were found to have the best performance, and the recovery rates obtained with this material and with the octadecyl solid phases were observed to correlate with the octanol-water partition coefficient of the pesticides (Geiss \& Gebert, 2006). Similar results were obtained when testing the extraction of nine herbicides from rice paddy fields water by (Roehrs et al., 2009). Another advantage of SPE is the possibility of automation (Petrovic et al., 2010).

Herbicides in environmental samples such as river, sea or agricultural water are generally highly diluted; therefore a high level of enrichment is required for their detection. As the instruments improve their sensitivity, the pre concentration factor required previous to the analysis is smaller. In reported literature concerning water analysis, as time pass by, the amount of sample required for the analysis is smaller with the clear trend to reduce the sample clean up and pre concentration of the sample.

Ten years ago, Jeannot et al., described two different methods for the analysis of triazines and sulphonylureas in surface waters. They used 0.5-10 L of sample for a liquid-liquid extraction with dichloromethane and two different solid phase extractions (SPE) using the Carbopack B (graphitized carbon black) and the C-18 bonded silica cartridge. The recoveries for each of these methods varied from $83-93 \%$ in liquid-liquid mode with RSD between 2$10 \%, 60-96 \%$ in SPE mode on Carbopack B with RSD 3-17\% and $67-100 \%$ in SPE C-18bonded silica mode with RSD 2-7\% (Jeannot et al., 2000).

In 2003 Zanella et al., validated a method for the determination of 2,4-D, quinclorac, bentazone, clomazone and propanil in surface and agriculture waters. The method was applied for levels between 0.1 and $0.5 \mathrm{mgL}^{-1}$ after a 500 -fold-pre-concentration with recoveries ranging from 85.7 to $109.8 \%$ and RSD of 1.8 to $13.4 \%$ analyzed by HPLC with UV detection (Zanella et al., 2003). HPLC-DAD was also employed for the determination of these herbicides plus four sulphonylureas, cyhalofop-butyl and bispyribac-sodium but using an OASIS HLB cartridge in tap and rice paddy field waters (Roehrs et al., 2009). The concentration level achieved was 1000 fold detecting herbicides at concentration as low as 40 $\mathrm{ngkg}^{-1}$ for tap water and $0.3 \mu \mathrm{gkg}^{-1}$ for paddy field water. 
Ayano et al., in 2004, described a multianalyte method for the determination of five sulphonylureas and three ureas in water. The analysis consisted on a SPE extraction with a polystyrene polymer cartridge (PS2), and ODS C-18-bonded silica cartridge (C-18) and an Nvinylpyrrolidone polymer cartridge (OASIS). The analytes determination and quantitation were performed by liquid chromatography with mass spectrometry (LC-MS). Average recoveries of the eight analytes from water samples were in the range $70-120 \%$ with relative standard deviations (RSD) below 20\% and the LOQs were between 10 and 100ngL-1 (Ayano et al., 2004).

Carabias-Martínez et al., in 2004, developed a method for the simultaneous determination of 10 sulphonylurea and phenylurea herbicides and one of their most common degradation products (3-chloro-4-methyl-phenyl urea) in water. In this procedure LC with diode array UV detection and electrospray mass spectrometry (LC-ESI/MS) in the positive mode were used for the separation, identification and quantification of the selected analytes. A 1000fold-pre-concentration step based on solid phase extraction was applied for the simultaneous extraction of sulphonylureas and phenylureas from water samples. Three different types of sorbents were compared, silica-based C-18, Oasis HLB and LiChrolut EN obtaining the highest recoveries (70-95\%) with the Oasis HLB cartridges (Carabias-Martínez et al., 2004). In 2006, Polati et al., presented the determination of 6 sulphonylureas in surface water. The methodology consisted on a pre concentration/SPE step using a Strata RP-18 E and two polymeric phases, Strata-X and Lichrolut EN, followed by HPLC-UV (240nm)-MSn analysis. After a 1000/1 pre-concentration the LODs were lower than $26.9 \mathrm{ngL}^{-1}$ with recoveries around $81-113 \%$ and RSD in the range 10-22 \% (Polati et al., 2006).

Kuster et al., in 2007, described the analysis of 14 polar herbicides in the Ebro river delta, during the main growing season of rice, by an automated on-line solid phase extraction followed by liquid chromatography tandem mass spectrometry.

The extraction of the herbicides was performed with polymeric cartridges Hysphere Resin GP (polydivinilbenzene), $10 \mathrm{~mL}$ samples were loaded onto the cartridge and the target analytes were eluted directly onto the chromatography column. The detection was performed using a triple quadrupole (QqQ) mass spectrometer and the electrospray interface was operated in both positive and negative mode. Some of the selected herbicides presented difficulties in their recoveries such as alachlor, molinate, propanil, diuron, chlorotoluron, with recoveries below $60 \%$ and atrazine, metolachlor, cyanazine with recoveries higher than $120 \%$ (Kuster et al., 2007). When analyzing complex matrixes, with minimal work up, matrix effects are noticeable in LC-MS/MS methods and can influence notably the results (identification, quantification and confirmation). The major matrix interferences are due to co-eluting compounds from the sample matrix that can affect the analyte ionization process leading to a signal enhancement or signal suppression. Different approaches have been proposed to overcome matrix effects: sample clean-up, the standard additions method, use of matrix-matched standards, a simple sample dilution if the instrument provides enough sensitivity, but the most widely method employed involves the use of appropriate internal standards. Environmental waters have high sample composition variability and it is difficult to find representative water samples that can be employed for blank determinations and method validation. The problem is still present when using the same type of water (surface, ground) because of their different origin. Therefore, the use of matrix-matched standards, widely applied in analysis of fruits and vegetables, does not provide a straightforward solution in the environmental field. If it is not possible to apply the "dilute and shoot" methodology, the use of analyte isotope-labelled internal standard is 
the preferred method to avoid matrix effects influence. This approach has some drawbacks, as only a limited number of reference standards of all possible contaminants are available which are also very expensive. Sometimes other compounds with similar chromatographic properties or structural analogues of the analytes are used but the obtained data is no always good enough (Marín et al., 2009). These authors compared the matrix effects from seven different types of water either using HPLC or UHPLC and the use of labeled internal standards to quantitate 37 pesticides using nine labelled internal standards (I.S). They concluded that in environmental waters, matrix effect was generally a negative effect but no general rules can be applied. Only the labelled pesticide as I.S assured a good correction. Nevertheless for not too loaded waters, the uncorrected values were satisfactory.

In 2009, Mazzella et al. developed a method for the simultaneous determination of 30 triazines, phenylurea and chloroacetanilide herbicides in fresh and estuarine waters, this work addresses two objectives; the development of an accurate method based on ESIMS/MS detection and the investigation of matrix effects. The pre concentration of the analytes was accomplished by using SPE with Oasis HLB cartridges, with recoveries between 73 to $122 \%$ and RSD ranged from 6 to $22 \%$ (Mazzella et al., 2009).

Ouyang et al., evaluated the performance of different SPE sorbents for the analysis of 10 sulphonylureas herbicides. The sorbents studied were: silica-based ODS-C18 and two polymeric sorbents, Oasis HLB and Cleanert HXN. Analytes determination and quantitation was carried out with liquid chromatography with electrospray mass spectrometry equipped with ion trap analyzer. The recovery rates range from 76.6 to $109.1 \%$ with RSD between 0.3 to $13.8 \%$ with the HLB cartridges which was the best one of the three cartridges evaluated (Ouyang et al., 2009).

Also gas chromatography, mainly with MS detection, has been extensively employed for the measurement of herbicide residues in water; different methods had been reported in the literature.

A GC-MS method was developed for the detection of triazine herbicides (atrazine, cyanazine, simazine) and their decomposition products (deethylatrazine, deisopropylatrazine) in environmental waters. The water samples were extracted using an octadecylsilica SPE cartridge with recoveries and RSD in their acceptable ranges (Ma et al., 2003).

SPME combined with GC-MS was developed and employed for the determination of 10 herbicides (alachlor, atrazine, chlorotoluron, diclofop, diflufenicam, ethofumesata, isoproturon, linuron, terbutryn and trifluralin) in surface and ground water. Microextraction was performed with a polyacrylate fiber. It was found that thermally unstable phenylurea herbicides decompose and the resulting anilines can be used for their identification. The recovery of herbicides varied between $94 \pm 16$ and $107 \pm 12 \%$ and the detection limit was below $1 \mu \mathrm{g} \mathrm{L}-1$. It was stated that the method is sensitive, reproducible, easy to perform, and can be applied for the quantitative determination of these herbicides in water (Carabias-Martínez et al., 2003a; Carabias-Martínez et al., 2003b).

In 2008 Crespo-corral et al., describe the determination of carbamate, phenylurea and phenoxy acid herbicide residues by gas chromatography after a potassium terbutoxide/dimethyl sulphoxide/ethyl iodide derivatization reaction. The method consisted on the pre concentration of the sample using a C-18 sep-Pack cartridge followed by the derivatization of the extract for the analysis with GC-FID and GC/MS in electron impact (EI) and selected ion monitoring mode. The recoveries were in the range $81-99 \%$ with RSD 0.9-20.6\% (Crespo-Corral et al., 2008).

As a curiosity, phenoxy herbicides have been detected even in rainfall waters in Canada (Hill et al 2002). 


\section{Herbicide residues analysis in soil}

Because of the possible strong binding of herbicides to the polar or apolar components of soil and sediment, the use of an appropriate extraction and pre concentration method is the pre requisite of a reliable chromatographic analysis (Cserháti, 2004). The analysis of pesticides in solid environmental matrices, such as soil, sewage, sludge and sediments, has been addressed in much fewer occasions than in water, probably because of the comparatively greater complexity of the matrices and the absence of environmental quality standards (EQS).

The first and probably the most important step in pesticide residue analysis in soils is soil characterization. There are many reports in the bibliography showing that the efficiency of the extraction method is highly dependent not only on the nature of the soil but also the amount of organic matter in it, being of paramount importance (Merini et al., 2008, Niell et al., 2010). Many nonpolar herbicides are adsorbed to soil organic matter and the cationic herbicides bind tightly to humic acids.

\subsection{Sample conservation}

In case that the soil sample will not be analyzed immediately, freezing to $-20^{\circ} \mathrm{C}$ is a reasonable measure. Nevertheless, care should be taken if the moist sample is frozen. Sample defrosting takes several hours and during this period microbial growth is exponential and biodegradation of pesticides can occur. Therefore, to prevent the microbial degradation of herbicides it is advisable to freeze-dry the sample and store it properly afterwards. Soil samples without water are easy to handle and to subsample to perform the analysis. To develop the method, the blank soil sample employed has to be treated as the real samples will be handled. Soils can be either reconstructed adding water or extracted directly with the extraction solvent. Nevertheless, it has to be considered that the dryness of the soil increase the clay portion of the soil sorption capacity (Haouari et al., 2006), (Merini et al., 2008), (He et al., 2006) but when water is added the interaction of the herbicide with the humic matter of the soil is increased. These authors also found that the recoveries of $2,4 \mathrm{DCP}$ were higher as the water amount of the soil was increased. It is desirable therefore to standardize the water content to the soil by adding a precise amount of water prior of conducting the extraction of the herbicides trapped in the soil.

\subsection{Spiking procedure}

During the development and validation of the analytical method for soil analysis, the spiking procedure is a crucial step for a successful appropriate analytical method. Pesticides interact in different ways with soils making the reconstruction of that situation in vitro a difficult task. Given that is almost impossible to overcome handicap, there are other points that have to be considered: Spiking solvent selection, volume of the spiking solution, sample homogenization, temperature for solvent evaporation. Merini et al., in 2008, evaluated such parameters for Argentinean loamy soils. They have found that $>80 \%$ recovery of $2,4 \mathrm{D}$ was obtained using $2000 \mu \mathrm{l}$ of Methanol as spiking solvent but recoveries were lower using lower volumes. When water was used for spiking, the recoveries dropped down to $<50 \%$.

\subsection{Extraction solvents}

Neutral analytes can be easily extracted using polar organic solvents $(\mathrm{MeOH}, \mathrm{ACN})$ or aqueous (MeOH: $\left.\mathrm{H}_{2} \mathrm{O},\left(\mathrm{CH}_{3}\right)_{2} \mathrm{CO}: \mathrm{H}_{2} \mathrm{O}\right)$ solutions of organic solvents. Ionic herbicides need water solutions to extract them from soils. In many cases, in order to minimize Van der Waals interactions between clay and humic acids, electrolytes like $\mathrm{KCl}$ can be employed to 
give enough ionic force to the solution to displace the herbicides from the soil. In some cases, the electrolyte also gives an adequate $\mathrm{pH}$ to get the most soluble form of the herbicide and to break the interaction with charged soils particles. Particularly sulphonylureas can be easily extracted with $\mathrm{MeOH}$ : Aq.0.1M $\left(\mathrm{NH}_{4}\right)_{2} \mathrm{CO}_{3}(1: 9)$ from different types of soils having either low or high organic matter content. Nevertheless, the method failed to yield good recoveries from other compounds like cyhalofop-butyl or bentazone. Also ionic compounds like bispyribac sodium cannot be recovered properly (Niell et al., 2010). The most employed herbicides nowadays cannot stand a thermally conducted extraction using methodologies such as MASE or Soxhlet. Pressurized Solvent Extraction and supercritical $\mathrm{CO}_{2}$ extraction with polar solvents as modifiers are methodologies usually reported for herbicide analysis, but room temperature extractions either ultrasonic or shaker stirred still are the preferred methodologies to perform herbicide extraction from soils. (Baugros et al., 2009; GarcíaValcarcel \& Tadeo, 2009). An example of the influence of the extraction solvents and extraction methodology is shown in the following example. Six chemically different herbicides residues (three sulphonylureas, bentazone, bispyribac-sodium and cyhalofopbutyl) were extracted from four soils of different compositions commonly employed for rice cultivation in Uruguay. The results are shown in Figure 2
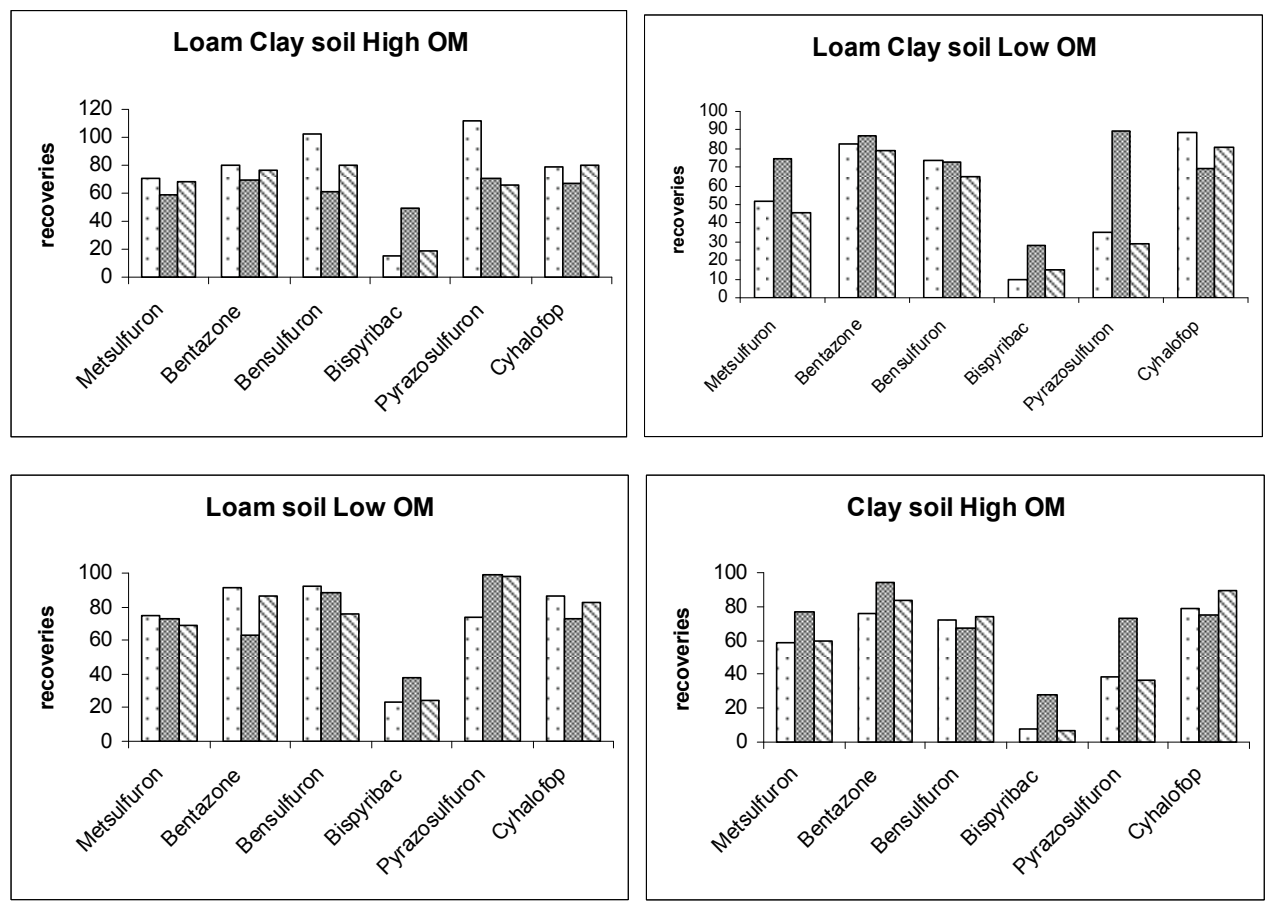

Fig. 2. Recoveries of herbicides from different soil types using two different extraction solvents and two different sitrring procedures (Heinzen et al, unpublished)

$\square \mathrm{MeOH}$ : AcOEt (7:3),Ultrasonic bath for 15 minutes

圈 MeOH: $0.1 \mathrm{M}\left(\mathrm{NH}_{4}\right)_{2} \mathrm{CO}_{3}(1: 9 ; \mathrm{v} / \mathrm{v})$, magnetic stirred.

$₫ \mathrm{MeOH}$ : AcOEt (7:3), magnetic stirred. 
Herbicide recoveries depend on the soil type and the extraction procedure. Different recoveries were observed for the herbicides depending On the type of soil. As a general trend it can be observed that the amount of organic matter usually decreases herbicide recoveries either in clay or loamy soils and the recoveries from loam soils are better than those obtained from clay soils. Aqueous solution of high ionic strength with 10\% Methanol gave better recoveries when extracting herbicides from clay soils. Even if the same solvent is used, the stirring method, either ultrasound or magnetic stirring, influences the overall herbicide recovery.

Synthetic herbicides are active at very low doses. Table 6 shows the usual application doses of imidazolinones, sulfonylureas and some individual compounds that are employed worldwide.

\begin{tabular}{|c|c|c|}
\hline Herbicide & $\mathbf{~ k g ~ h a}^{-1}$ & $\left.\mathbf{~ k g m}^{-2} \mathbf{( x 1 0 - 6}\right)$ \\
\hline Sulphonylureas & $0.3-0.5$ & $3-5$ \\
\hline Imidazolinones & $0.1-0.35$ & $1-3.5$ \\
\hline Alachlor & $0.5-2.0$ & $5-20$ \\
\hline Clomazone & 1.1 & 11 \\
\hline Metribuzin & 0.57 & 6 \\
\hline Quinclorac & $5-10$ & $50-100$ \\
\hline
\end{tabular}

Table 6. Application dose of herbicides per area unit

The concentration of the herbicide applied per $\mathrm{m}^{2}$ is within the $\mathrm{mg}$ range. Taking into account that usually a $1 \mathrm{~kg}$ soil sample is made from mixing many subsamples that covered approximately a $10 \times 20 \mathrm{~cm}$ of the superficial soil, the amount of herbicide to be detected is in the sub milligram range or ppbs.

In a miniaturized protocol, usually less than $20 \mathrm{~g}$ of soil are employed for residue analysis. The detection and quantitation procedure must be sensitive enough to detect the compounds under investigation at such level. The physicochemical properties like the Henry's law constant and Kow shows that most of the herbicides are either polar or not volatile enough to be GC-analyzed. Nevertheless, in the past, GC/ECD, NPD or sQuad MS operating in the SIM mode detectors were the method of choice to quantify the agrochemicals searched. In many cases, a derivatization step was mandatory as for phenoxy auxin herbicides sometimes indirect detection of the analytes was the only option: thermolabile herbicides like ureas are detected as the corresponding anilines (Berrada et al., 2004). Phenylureas, can be determined directly by GC but some derivatization reactions have been reported to obtain less polar and more volatile compounds. Some of the reagents commonly used are the alkyl iodide and heptafluorobutyric anhydride (HFBA), where the latest one gives very stable derivatization products with a high ECD response. This family of pesticides can also be determined as their thermal decomposition products (isocyanates) that may be obtained quantitatively under closely controlled conditions (Tadeo et al., 2000). Phenylureas also decompose to the corresponding anilines in the GC injection port. This property was applied (Berrada et al., 2004) for the GC determination of phenylureas after MSPE extraction from vegetables with a polyacrilate fiber.

The other old instrumental approach was to use HPLC coupled to UV and fluorescence detectors and later on sQuadMS. The fluorescence detector is very sensitive and selective, and applying pre or post column derivatization, very complicated analytes like glyphosate and AMPA have been routinely analyzed worldwide since twenty years ago. 
On the other hand UV detection has many interferences from the soil matrix as it is neither as sensitive nor as specific towards analytes in complex mixtures. Nevertheless, they have been used for years. (Patsias et al., 2002, Niell et al., 2010) Normally, the detection level is Not lower than $0.1 \mathrm{mgkg}^{-1} \mathrm{~L}^{-1}$ in the injected sample. Therefore, sample size must be increased and the extracting solution concentrated in order to get enough analyte to be detected. The main disadvantage is that the other matrix components also concentrate, yielding noisy chromatograms and the herbicide peaks are difficult to identify and in many cases impossible to quantify if a S/N 10:1 has to be reached. HPLC/MS operating in the SIM mode is a more powerful analytical tool and many problems had been solved using this approach, but mainly focused on single residue analysis. The MS detector is also a universal one and interferences from matrices are common, driving to false positives in many cases.

LC-MS/MS techniques are the most powerful methods for pesticide trace analysis particularly herbicides. They offer the possibility of selectively analyze the fragmentation of an ion which was ionized in the first MS cycle. The selectivity achieved and the sensitivity is also remarkable. This advance in the detection and quantitation of trace compounds boosted the strict EU-regulations on contaminant levels allowed in different food matrices. Screening of contaminants is performed mainly with Time of flight instruments (ToF), in MS or MS/MS modes. ToF instruments can determine exact masses for the compounds detected and therefore, unequivocal identification of the analyte is performed. Sorbents used for online SPE or MSPE extraction have included both traditional (alkylbonded silica and polymers) (Djozan \& Ebrahimi, 2008) and novel molecular imprinted polymers (MIP) materials. MIPs have been proven to be valuable materials for the selective extraction of pesticides (the template molecule and structurally related compounds). The inherent selectivity of the molecular recognition of these materials allows a high degree of sample clean-up to be achieved (Cacho et al., 2009). Zhang et al., reports the preparation of a new non-covalently bonded MIP and its evaluation for pre concentration of metribuzin in soil samples, this MIP was prepared by in-situ polymerization using methacrylic acid (MAA) as the functional monomer and ethylene glycol dimethacrylate (EDMA) as cross-linker. An online procedure was, furthermore, employed for the quantitative determination of metribuzin with pre concentration on the monolithic polymer pre-column. MIP can be combined with stir bar extraction for the determination of nicosulfuron (Yang et al., 2010), achieving a sensitivity for water and soils at the $\mathrm{nM}$ level. The sample preparation consisted on the maceration of $25 \mathrm{~g}$ of soil sample with acetone: water (4:1), followed by filtration and later extraction with dichloromethane in the presence of $20 \%$ sodium chloride solution. This sample solution was concentrated and analyzed directly with the on-line procedure. The effectiveness of the MIP was evaluated by LC (Zhang et al., 2009).

In 2008, Lesueur et al., compared four different extraction methods for the analysis of 12 herbicides and two transformation products. The methods were a) ultrasonic solvent extraction (USE) consisting on the extraction of $20 \mathrm{~g}$ of sample with a 1:2 solution of water/acetonitrile, b) a PLE experiment where $5 \mathrm{~g}$ of sample were mixed with $1 \mathrm{~g}$ of silica gel and extracted with acetonitrile/acetone (1:1), c) QuEChERS method and d) European Norm DIN 12393. The analyses were performed by using a LC tandem mass spectrometry system equipped with an electrospray ionization interface operated in positive mode. The lowest recoveries were obtained with the USE method; on the contrary the higher recoveries were obtained with QuEChERS method, between 27-120\%. Nevertheless, the lowest limits of detection were obtained with the European Norm DIN 12393 and the highest with QuEChERS and PLE methods (Lesueur et al., 2008). 
In 2009, Wu et al., analyzed four sulphonylureas by dispersive solid-phase extraction (dSPE) followed by dispersive liquid-liquid microextraction (DLLME) and HPLC. The dSPEDLLME procedure consisted on the extraction of $10 \mathrm{~g}$ of soil with $20 \mathrm{~mL}$ acetone/0.15 M $\mathrm{NaHCO}_{3}$ (2:8) vigorously shaken for $30 \mathrm{~min}$. For dSPE $0.15 \mathrm{~g}$ of C-18 per $10 \mathrm{~mL}$ extract was added and shaken. For the DLLME $5 \mathrm{~mL}$ aliquot of the extract were mixed with $60 \mu \mathrm{L}$ chlorobenzene (as extraction solvent), after vortexing and centrifugation the chlorobenzene residue was dissolved in acetonitrile and analyzed by HPLC. The recovery rates varied from $76-93 \%$ with RSD from 5 to $7 \%$. The authors noticed that compared with other conventional sample preparation methods, this analytical technique offers advantages such as simplicity, ease operation, relatively short analysis time, and lower consume of solvent $(\mathrm{Wu}$ et al., 2009). Ionic fluids, one of the most popular class of green solvents, are interesting solvents for performing DLLME of herbicides either in water or soil and food aqueous extracts. A room temperature ionic liquid, 1-hexyl-3-methylimidazolium hexafluorophosphate $\left(\left[\mathrm{C}_{6} \mathrm{MIM}\right]\left[\mathrm{PF}_{6}\right]\right)$, was used as extraction solvent and Triton $\mathrm{X} 114$ was used as dispersant. A mixture of $175 \mu \mathrm{L}$ of $\left(\left[\mathrm{C}_{6} \mathrm{MIM}\right]\left[\mathrm{PF}_{6}\right]\right)$ and $50 \mu \mathrm{L} 10 \%$ Triton $\mathrm{X} 114$ was rapidly injected into the $20 \mathrm{~mL}$ honey sample by syringe. Herbicides (chlortoluron, prometon, propazine, linuron and prebane) residues were quantified below the $0.01 \mathrm{mgkg}^{-1}$ range (Wang, 2010).

Sulphonylureas have been detected in Canadian wetlands sediment where no agriculture activities had been performed (Degenhart et al., 2010) and in a real situation, a Multirresidue method by Pressurized Liquid Extraction and GC of vineyard soils allowed the simultaneous and GC allowed the simultaneous determination of two herbicides, three fungicides and two Insecticides at ppb level (Schreck et al., 2008).

Diez et al., studied the soil dissipation kinetics of 12 herbicides used on a rain-fed barley crop, the extraction of the soils was carried out with a mixture of acetone, water, and acetic acid (30:7.5:0.3) followed by the analysis in a GC/MS. The extraction method was previously validated for the extraction of 40 herbicides in soils, with recoveries between $71-108 \%$ and RSD in the range 0.6-8\% (Díez et al., 2008; Díez \& Barrado, 2010). The determination by GC(ITD)MS/MS of triazines, alachlor and metabolites from soils was also performed after Microwave Assisted Extraction (Vryzas et al., 2007).

\subsection{Herbicide residues analysis in cereals.}

Analysis of herbicide residue involves different steps such as extraction, interference removal, determination of the herbicide residues and their confirmation. All these analysis are generally performed by using several analytical techniques.

The determination of herbicides was initially carried out by colorimetric and spectrophotometric methods but the sensitivity was not enough to meet the regulations and therefore more sensitive methods have been created in order to reach the limits of detection demanded.

The extraction techniques used for the analysis of herbicide residue in cereals depends on the characteristic of the matrix and the polarity of the herbicides.

In recent years, the development of multiresidue methods (MRM) has taken a high profile, however, there are several pesticides that cannot be included in MRM thus single residue methods (SRM) has to be implemented, which means more workload and expenses for the laboratories (Poulsen et al., 2009).

Some examples of herbicides which need these kinds of SRM are glyphosate and their metabolites, acidic herbicides or trazines. Table 7 summarizes different MRM which involve 
the determination of herbicides in cereals used during cereals cropping, while in Table 9 the main single extraction methods for some important herbicides are also presented.

Another important factor that the analyst has to take into account is whether the sample suffered an industrial process or if it is raw material. During cereal processing specially during the milling step a big part of the fats components, which are generally found in the bran, are lost. This is an advantage from an analytical point of view, because the sample treatment will not be so exhaustive.

\subsection{Extraction and clean-up}

Extraction of herbicides from food depends on their polarity and also on the type of matrix. Generally it consists on the homogenization of the sample with an organic solvent alone or mixed with water or $\mathrm{pH}$ adjusted, using an ultrasonic bath, a blender or a homogenizer (Lambropoulou \& Albanis, 2007).

After the extraction process generally a clean-up procedure is carried out in order to remove the co-extracted compounds that may act as interference during the chromatographic analysis, causing problems in the detection and quantitation of the analytes.

As discussed before, extraction of residues from food depends strongly on the polarity of the selected herbicides, but also on the selectivity and sensitivity of the detection technique employed in their determination.

Nowadays, one of the most used MRM method is QuEChERS (Quick, Easy, Cheap, Effective, Rugged and Safe) but for certain herbicides the use of PSA during the clean-up, or the $\mathrm{pH}$ during the extraction causes low recoveries due to poor extraction or chemical interaction with the PSA sorbent. Therefore, several modifications have been implemented in order to improve the recoveries for these kinds of herbicides (CRL website; Anastassiades et al., 2003; Lehotay et al., 2005).

Despite the fact that in routine analysis laboratories prefer the use of few methods with a wide scope, some pesticides, especially some kinds of herbicides require particular extraction conditions and / or clean-up.

The most used herbicides in cereal cropping belong to the phenoxy, phenyl and sulphonylurea families of herbicides. Nevertheless, there are some others like glyphosate, propanil, bentazone (a banned herbicide within the EU) that are also widely used (Herrmann et al., 2006).

This section is focused on the analytical techniques for the determination of most of these herbicides.

The phenoxy herbicides are widely applied as salts or esters but they decompose by hydrolysis, in the plant, to their respective acids thus the extraction of these herbicides is generally carried out with high polarity organic solvents such as $\mathrm{MeOH}, \mathrm{EtOH}$ or mixtures with water. However these herbicides are best analyzed when they are extracted as their free acids. In general, both acid and basic hydrolysis followed two different strategies. On one hand, samples are hydrolyzed and the free acids extracted with an organic solvent. On the other hand, the parent herbicide and its conjugates are extracted by organic solvents and subsequently hydrolyzed.

Table 7 summarizes the main methodologies used for the analysis of these herbicides in cereals. 


\begin{tabular}{|c|c|c|c|c|}
\hline Matrix & $\begin{array}{l}\text { Extraction } \\
\text { Procedure }\end{array}$ & Clean-up & Ref. & Analytical Technique \\
\hline $\begin{array}{c}\text { Unpolished } \\
\text { Rice }\end{array}$ & $\begin{array}{l}\text { Pressurized Liquid } \\
\text { Extraction }\end{array}$ & $\begin{array}{l}\text { LLE/SPE:ENVI- } \\
\text { Carb/LC-NH } 2\end{array}$ & $\begin{array}{c}\text { (Itoh et al., } \\
2009)\end{array}$ & $\begin{array}{c}\text { Liquid Chromatography } \\
\text { Atmospheric Pressure } \\
\text { Photoionization mass } \\
\text { spectrometry }\end{array}$ \\
\hline $\begin{array}{l}\text { Polished } \\
\text { rice }\end{array}$ & $\begin{array}{l}\text { QuEChERS (1\% } \\
\text { HAc in MeCN) }\end{array}$ & --- & \begin{tabular}{|c|} 
(Niell et al., \\
$2010)$
\end{tabular} & $\begin{array}{l}\text { Liquid chromatography } \\
\text { DAD detection }\end{array}$ \\
\hline Barley & QuEChERS & MSPD: PSA, $\mathrm{MgSO}_{4}$ & $\mid \begin{array}{c}\text { (Díez et al., } \\
2006)\end{array}$ & $\begin{array}{l}\text { Liquid Chromatography } \\
\text { tandem mass } \\
\text { spectrometry } \\
\text { Gas Chromatography- } \\
\text { time of flight-mass } \\
\text { spectrometry }\end{array}$ \\
\hline $\begin{array}{c}\text { Unpolished } \\
\text { Rice }\end{array}$ & $\begin{array}{l}\text { Supercritical Fluid } \\
\text { Extraction }\end{array}$ & \begin{tabular}{|c|} 
SPE: BondElut ${ }^{\circledR}$ PSA \\
over Sep-Pak ${ }^{\circledR}$ \\
Florisil column \\
connected in tandem \\
\end{tabular} & $\begin{array}{c}\text { (Kaihara et } \\
\text { al., 2002) }\end{array}$ & $\begin{array}{c}\text { Liquid } \\
\text { Chromatography- } \\
\text { Electrospray Ionization } \\
\text { mass spectrometry } \\
\end{array}$ \\
\hline Rice & $\begin{array}{c}\mathrm{CH}_{2} \mathrm{Cl}_{2} \text { ultrasonic } \\
\text { bath }\end{array}$ & SPE: Florisil & $\begin{array}{c}\text { (Pengyan et } \\
\text { al., 2006) }\end{array}$ & $\begin{array}{c}\text { Gas Chromatography } \\
\text { mass spectrometry by } \\
\text { selected ion monitoring } \\
\text { mode }\end{array}$ \\
\hline $\begin{array}{c}\text { Cooked } \\
\text { polished } \\
\text { rice, wheat }\end{array}$ & $\begin{array}{l}\text { MeCN, shaker, } \\
\text { ultrasonic bath }\end{array}$ & --- & $\begin{array}{c}\text { (Lee et al., } \\
2009)\end{array}$ & \begin{tabular}{|c|} 
Liquid \\
Chromatography- \\
Electrospray Ionization \\
mass spectrometry
\end{tabular} \\
\hline Rice & QuEChERS & $\begin{array}{c}\text { MSPD: PSA, } \mathrm{MgSO}_{4} / \\
\text { GPC }\end{array}$ & \begin{tabular}{|c|} 
(Liu et al., \\
$2007)$
\end{tabular} & $\begin{array}{l}\text { Gas Chromatography } \\
\text { mass spectrometry }\end{array}$ \\
\hline Rice & QuEChERS & MSPD: PSA, MgSO4 & $\begin{array}{c}\text { (Libin et al., } \\
2006)\end{array}$ & $\begin{array}{l}\text { Gas Chromatography } \\
\text { mass spectrometry }\end{array}$ \\
\hline Rice & QuEChERS & $\begin{array}{c}\text { Supelclean ENVI-18 } \\
\text { cartridge/Supelclean } \\
\text { ENVI-carb II/PSA } \\
\text { cartridge. }\end{array}$ & $\begin{array}{c}\text { (Takatori et } \\
\text { al., 2008) }\end{array}$ & $\begin{array}{c}\text { Liquid } \\
\text { Chromatography- } \\
\text { Electrospray Ionization } \\
\text { mass spectrometry }\end{array}$ \\
\hline Rice & QuEChERS & $\begin{array}{c}\text { MSPD: } \mathrm{PSA}, \mathrm{MgSO}_{4} \\
\mathrm{GCB}\end{array}$ & $\begin{array}{c}\text { (Nguyen et } \\
\text { al., 2007) }\end{array}$ & $\begin{array}{c}\text { Gas Chromatography } \\
\text { mass spectrometry by } \\
\text { selected ion monitoring } \\
\text { mode }\end{array}$ \\
\hline $\begin{array}{c}\text { Unpolished } \\
\text { rice }\end{array}$ & $\begin{array}{l}\text { Ethylacetate, } \\
\text { homogenizer }\end{array}$ & GPC/ SPE Florisil & $\begin{array}{l}\text { (Zhang et } \\
\text { al., 2006) }\end{array}$ & $\begin{array}{c}\text { Gas Chromatography } \\
\text { mass spectrometry by } \\
\text { selected ion monitoring } \\
\text { mode }\end{array}$ \\
\hline Rice & QuEChERS & $\begin{array}{c}\text { MSPD: } \mathrm{PSA}, \mathrm{MgSO}_{4} \\
\mathrm{GCB}\end{array}$ & $\begin{array}{c}\text { (Nguyen et } \\
\text { al., 2008) }\end{array}$ & $\begin{array}{c}\text { Gas Chromatography } \\
\text { mass spectrometry by } \\
\text { selected ion monitoring } \\
\text { mode }\end{array}$ \\
\hline
\end{tabular}




\begin{tabular}{|c|c|c|c|c|}
\hline Matrix & $\begin{array}{l}\text { Extraction } \\
\text { Procedure }\end{array}$ & Clean-up & Ref. & Analytical Technique \\
\hline $\begin{array}{c}\text { Rice, } \\
\text { wheat, } \\
\text { maize, } \\
\text { barley, oats }\end{array}$ & $\begin{array}{c}\text { Accelerated Solvent } \\
\text { Extraction }\end{array}$ & \begin{tabular}{|c|} 
a. ENVI-18 \\
cartridges/ENVIcarb \\
cartridges/Sep-Pak \\
$\mathrm{NH}_{2}$ cartridge \\
b. Sep-Pak Alumina \\
$\mathrm{N}$ cartridge/Sep-Pak \\
$\mathrm{NH}_{2}$ cartridge \\
\end{tabular} & $\mid \begin{array}{c}\text { (Pang et al., } \\
\text { 2006) }\end{array}$ & $\begin{array}{l}\text { a. Gas Chromatography } \\
\text { mass spectrometry, } \\
\text { b. Liquid } \\
\text { Chromatography- } \\
\text { Electrospray Ionization } \\
\text { mass spectrometry }\end{array}$ \\
\hline Maize & $\begin{array}{c}\text { a. Water } / 1 \% \text { formic } \\
\text { acid in } \mathrm{MeCN} \\
\text { b. Water } / 1 \% \text { formic } \\
\text { acid in } \mathrm{MeOH} \\
\text { c. Water } / 1 \% \text { formic } \\
\text { acid in acetone }\end{array}$ & --- & $\begin{array}{c}\text { (Mol et al., } \\
2008)\end{array}$ & $\begin{array}{l}\text { Ultraperformance liquid } \\
\text { Chromatography } \\
\text { electrospay ionization } \\
\text { mass spectrometry }\end{array}$ \\
\hline Soybean & $\begin{array}{c}\text { MeCN:acetone:light } \\
\text { petroleum (1:1:1), } \\
\text { homogenizer }\end{array}$ & GPC & $\begin{array}{c}\text { (Pizzutti et } \\
\text { al., 2007) }\end{array}$ & \begin{tabular}{|c|} 
Liquid \\
Chromatography- \\
Electrospray Ionization \\
mass spectrometry
\end{tabular} \\
\hline Soybean & $\begin{array}{c}\text { LLE (MeCN, } \\
\text { ethylacetate, } 1 \mathrm{M} \\
\text { phosphate buffer } \\
\text { pH } 7\end{array}$ & SPE: SAX/PSA & $\begin{array}{c}\text { (Hirahara et } \\
\text { al., 2005) }\end{array}$ & $\begin{array}{c}\text { Gas Chromatography. } \\
\text { Detectors FPD, ECD, } \\
\text { MSD }\end{array}$ \\
\hline $\begin{array}{l}\text { Wheat, } \\
\text { Rye, Rice, } \\
\text { Maize }\end{array}$ & $\begin{array}{c}\text { Buffered } \\
\text { QuEChERS }\end{array}$ & MSPD: PSA, $\mathrm{MgSO}_{4}$ & $\begin{array}{l}\text { (Herrmann } \\
\text { et al., 2006) }\end{array}$ & $\begin{array}{l}\text { Gas Chromatography } \\
\text { Ion trap Detection }\end{array}$ \\
\hline Wheat & $\begin{array}{l}\text { Citrate Buffered } \\
\text { QuEChERS }\end{array}$ & \begin{tabular}{|c|} 
MSPD: PSA, $\mathrm{MgSO}_{4}$, \\
$\mathrm{C}-18$
\end{tabular} & $\begin{array}{c}\text { (Walorckyk } \\
\text { 2007) }\end{array}$ & $\begin{array}{c}\text { Gas Chromatography } \\
\text { mass spectrometry }\end{array}$ \\
\hline Wheat flour & $\begin{array}{l}\text { Water/MeOH, } \\
\text { Ultra Turrax }\end{array}$ & $\mathrm{NaCl} /$ ChemElut & $\begin{array}{c}\text { (Klein \& } \\
\text { Alder, 2003) }\end{array}$ & \begin{tabular}{|c|} 
Liquid Chromatography \\
Electrospray \\
Ionization/atmospheric \\
pressure ionization mass \\
spectrometry
\end{tabular} \\
\hline $\begin{array}{l}\text { Wheat } \\
\text { Flour }\end{array}$ & $\begin{array}{l}\text { Citrate buffered } \\
\text { QuEChERS } \\
\text { Basic Hydrolysis } \\
\text { (optional) } \\
\end{array}$ & Freezing (optional) & $\begin{array}{c}\text { CRL } \\
\text { webpage }\end{array}$ & $\begin{array}{l}\text { Liquid Chromatography } \\
\text { Electrospray mass } \\
\text { spectrometry }\end{array}$ \\
\hline Wheat & $\begin{array}{l}\text { Citrate Buffered } \\
\text { QuEChERS }\end{array}$ & $\begin{array}{c}\text { MSPD: PSA, } \mathrm{MgSO}_{4}, \\
\mathrm{C}-18\end{array}$ & $\begin{array}{c}\text { (Walorckyk } \\
\text { 2008) }\end{array}$ & $\begin{array}{l}\text { Gas Chromatography } \\
\text { mass spectrometry }\end{array}$ \\
\hline
\end{tabular}

Table 7. Main methodologies used for the multiresidue analysis of herbicides in cereals.

Herbicides like molinate, atrazine, diuron are normally included and determined in many of the MRM methods listed above along with insecticides and funguicides (Cervera et al., 2010). The following example (Figure 3) shows the multiresidue analysis using HPLC-MS/MS of fifteen herbicides currently employed in rice production. Table 8 summarizes the most relevant analytical features of the analyzed pesticides. 


\begin{tabular}{|c|c|c|c|c|c|c|c|}
\hline Pesticide & Mode of action & $\begin{array}{c}\text { tR } \\
(\mathbf{m i n})\end{array}$ & $\begin{array}{c}\text { Quantitation } \\
\text { MRM1 }\end{array}$ & $\begin{array}{c}\text { Confirmation } \\
\text { MRM2 }\end{array}$ & $\begin{array}{c}\text { Fragmentor } \\
\text { (V) }\end{array}$ & $\begin{array}{c}\text { CE1 } \\
(\mathbf{e V})\end{array}$ & $\begin{array}{c}\text { CE 2 } \\
(\mathbf{e V})\end{array}$ \\
\hline $\begin{array}{c}\text { Azimsulfur } \\
\text { on }\end{array}$ & Sulphonylureas & 17.3 & $447.1 / 178.1$ & $425.0 / 182.1$ & $120 / 90$ & 10 & 15 \\
\hline $\begin{array}{c}\text { Bensulfuro } \\
\text { n-methyl }\end{array}$ & Sulphonylureas & 18.7 & $411.1 / 182.0$ & $411.1 / 149.0$ & 150 & 20 & 15 \\
\hline $\begin{array}{c}\text { Bispyribac } \\
\text { sodium }\end{array}$ & $\begin{array}{c}\text { pyrimidinyloxyben } \\
\text { zoic acid }\end{array}$ & 19.2 & $453.1 / 297.1$ & $453.1 / 179.1$ & 150 & 15 & 20 \\
\hline Bromacil & uracyl & 14.2 & $261.0 / 205.0$ & $261.0 / 188.0$ & 90 & 10 & 20 \\
\hline Clomazone & unclassified & 19.4 & $240.1 / 125.0$ & $240.1 / 89.0$ & 150 & 20 & 60 \\
\hline $\begin{array}{c}\text { Cyhalofop- } \\
\text { butyl }\end{array}$ & $\begin{array}{c}\text { aryloxyphenoxypro } \\
\text { pionic }\end{array}$ & 10.4 & $357.8 / 256.0$ & $357.8 / 302.0$ & $150 / 165$ & 40 & 12 \\
\hline Fluroxypyr & pyridine & 14.5 & $255.0 / 181.0$ & $255.0 / 209.0$ & 120 & 20 & 15 \\
\hline Imazapic & imidazolinone & 9.6 & $276.1 / 163.2$ & $276.1 / 145.0$ & 150 & 30 & 40 \\
\hline Imazapyr & imidazolinone & 6.5 & $262.1 / 149.1$ & $262.1 / 217.0$ & 150 & 30 & 30 \\
\hline Imazaquin & imidazolinone & 14.3 & $312.1 / 199.0$ & $312.1 / 153.2$ & $90 / 150$ & 30 & 50 \\
\hline $\begin{array}{c}\text { Imazosulfu } \\
\text { ron }\end{array}$ & Sulphonylureas & 18.6 & $413.1 / 156$ & $413.1 / 153.0$ & 150 & 20 & 5 \\
\hline Molinate & thiocarbamate & 21.4 & $188.2 / 126.1$ & $188.2 / 55.1$ & 80 & 10 & 20 \\
\hline $\begin{array}{c}\text { Pyrazosulfu } \\
\text { ron-ethyl }\end{array}$ & Sulphonylureas & 20.3 & $415.1 / 182.1$ & $415.1 / 139.1$ & $120 / 90$ & 25 & 50 \\
\hline $\begin{array}{c}\text { Propaquiza } \\
\text { fop }\end{array}$ & $\begin{array}{c}\text { aryloxyphenoxypro } \\
\text { pionic }\end{array}$ & 26.3 & $444.1 / 371.1$ & $444.1 / 100.1$ & 140 & 15 & 15 \\
\hline Quinclorac & $\begin{array}{c}\text { quinolinecarboxylic } \\
\text { acid }\end{array}$ & 14.4 & $242.0 / 223.0$ & $242.0 / 161.0$ & 90 & 10 & 40 \\
\hline
\end{tabular}

Table 8. Instrument acquisition data used for the analysis of the selected herbicides by LC$\mathrm{QqQ} / \mathrm{MS} \mathrm{tR}$, retention time, CE, collision energy.

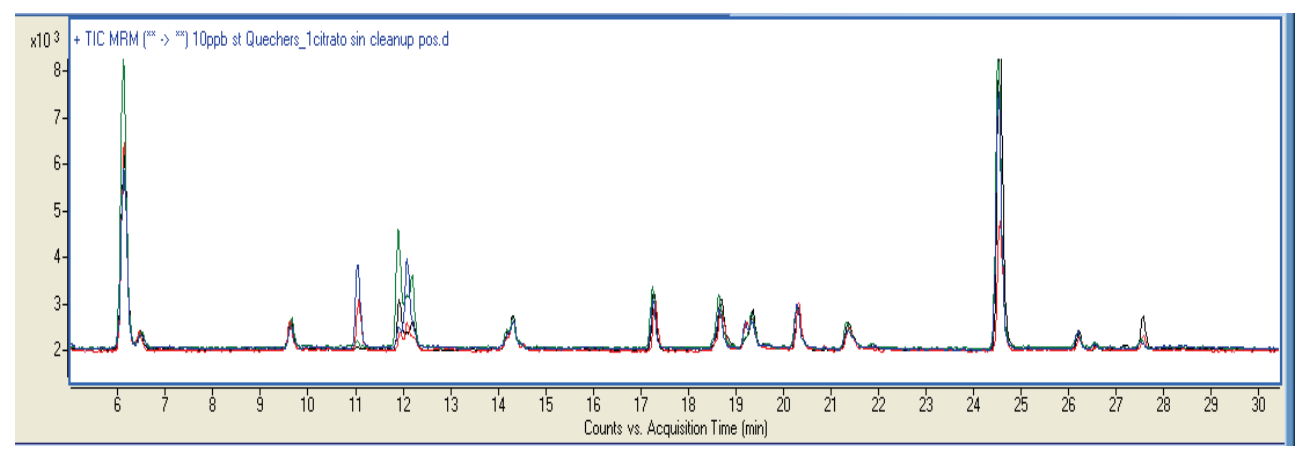

Fig. 3. Analysis of the selected herbicides by LC-QqQ/MS after different QuEChERS procedures at $5 \mu \mathrm{gkg}^{-1}$ (Pareja et al, unpublished)

For conditions see Table 8.

Different QueChERS based procedures allowed a good extraction and clean up of the complex rice matrix at very low levels, with recoveries ranging between $60-120 \%$ ( Pareja et al, 2009) 


\section{Single residue methods}

\begin{tabular}{|c|c|c|c|c|}
\hline Analyte & Matrix & Extraction Procedure: SRM & $\begin{array}{c}\text { \%Recovery } \\
\text { (\% RSD) }\end{array}$ & Ref. \\
\hline $\begin{array}{l}\text { Glyphosate, } \\
\text { chlormequa, } \\
\text { mepiquat }\end{array}$ & Wheat & $\begin{array}{l}\text { Glyphosate } 3 \mathrm{~g} \text { of wheat with } 25 \mathrm{~mL} \text { water were } \\
\text { extracted twice by ultrasonication. The extract was } \\
\text { centrifuged and filtered. The clean up was performed } \\
\text { by using a polystyrene reverse phase column. } \\
\text { Chlormequat, mepiquat } 10 \mathrm{~g} \text { of sample was extracted } \\
\text { with MeOH/water/acetic acid by ultraturrax. The } \\
\text { centrifuged extracts were clean-up on a SPE-C-18 } \\
\text { column with MeOH/water/ammonium acetate } \\
\text { buffer. }\end{array}$ & $89,93,90$ & $\begin{array}{l}\text { (Anderse } \\
\mathrm{n} \quad \text { et } \\
2007)\end{array}$ \\
\hline Glyphosate & Cereals & $\begin{array}{l}1 \mathrm{~g} \text { of grain flour with } 20 \mathrm{~mL} \text { water were vortexed for } \\
1 \mathrm{~min} \text {. Overnight standing extraction and then } \\
\text { centrifuged for } 10 \mathrm{~min} \text {. Clean up: } 1 \mathrm{~mL} \text { of the extract } \\
\text { was loaded into a preconditioned } 100 \mathrm{mg} \text { C-18- } \\
\text { bonded silica cartridge. The cartridge was placed on } \\
\text { top of a calibrated tube. } 1.5 \mathrm{~mL} \text { of the supernatant was } \\
\text { transferred into the cartridge and by means of over } \\
\text { pressure passed through the cartridge and collected } \\
\text { into the tube. }\end{array}$ & $\begin{array}{l}88-99 \\
(5.3-7.1) \\
\end{array}$ & $\begin{array}{l}\text { (Hogend } \\
\text { oorn et } \\
\text { al., 1999) }\end{array}$ \\
\hline $\begin{array}{l}\text { Fenoxaprop } \\
\text {-p-ethyl, } \\
\text { isoxadifen- } \\
\text { ethyl }\end{array}$ & Rice & $\begin{array}{l}25 \mathrm{~g} \text { of sample were extracted with } 40 \mathrm{~mL} \\
\text { acetonitrile/0.1M hydrochloric acid (80:20) and mixed } \\
\text { for } 10 \mathrm{~min} \text { on a shaker. The extract was filtered and } \\
\text { the paper washed twice with acetone. The filtrate was } \\
\text { loaded onto the Chemelut CE250 column and eluted } \\
\text { with } 150 \mathrm{~mL} \text { cyclohexane/ethylacetate, the eluate } \\
\text { evaporated to dryness. }\end{array}$ & $\begin{array}{l}74.1-98.3 \\
83.3-100.9\end{array}$ & $\begin{array}{l}\text { (Lucini \& } \\
\text { Molinari, } \\
2010)\end{array}$ \\
\hline $\begin{array}{l}\text { Chlormequ } \\
\text { at, } \\
\text { Mepiquat }\end{array}$ & $\begin{array}{l}\text { Wheat } \\
\text { and } \\
\text { other } \\
\text { cereals } \\
\text { flour }\end{array}$ & $\begin{array}{l}3 \mathrm{~g} \text { of flour were packed into a } 11 \mathrm{~mL} \text { extraction cell } \\
\text { and extracted with EtOH at } 100 \mathrm{~atm} \text { at } 120^{\circ} \mathrm{C} \text { with an } \\
\text { extraction time of } 15 \mathrm{~min} \text { divided as follows: } \\
\text { preheating (1min), heating ( } 8 \mathrm{~min} \text { directly set by } \\
\text { microprocessor on the grounds of the selected } \\
\text { temperature value), static step (5 min) and purging (1 } \\
\text { min). Subsequent to extraction } 50 \mu \mathrm{L} \text { of IS solution } \\
\text { were added to each sample. }\end{array}$ & $83-99$ & $\begin{array}{l}\text { (Marches } \\
\text { e et al., } \\
2009)\end{array}$ \\
\hline Triazines & $\begin{array}{l}\text { Cereal- } \\
\text { based } \\
\text { foods }\end{array}$ & $\begin{array}{l}\text { PMAE. } 2 \mathrm{~g} \text { of sample with } 20 \mathrm{~mL} \text { MeOH were placed } \\
\text { in the extraction vessel. The magnetron power was set } \\
\text { at } 100 \%(600 \mathrm{~W}) \text {. The extraction temperature increased } \\
\text { gradually until it reached } 105{ }^{\circ} \mathrm{C} \text { in that moment the } \\
\text { extraction was performed for } 10 \text { min. After the } \\
\text { completion of the extraction the vessels were allowed } \\
\text { to cool at room temperature for } 20 \text { min. The extract } \\
\text { was filtered and the sediments were rinsed } 3 \text { times } \\
\text { with MeOH. The mixture was dried by rotatory } \\
\text { evaporator at } 45^{\circ} \mathrm{C} \text { and redissolved in acetonitrile. } \\
\text { AMAE. } 2 \mathrm{~g} \text { of sample were refluxed with } 40 \mathrm{~mL} \\
\text { MeOH for } 20 \mathrm{~min} \text { in a modified household microwave } \\
\text { oven with } 30 \% \text { output maximum power of } 800 \mathrm{~W} \text { and } \\
\text { a distilling flask fitted with water cooling condenser } \\
\text { tube. The extract was filtered and the sediments were }\end{array}$ & $\begin{array}{l} \\
71.9-83.7 \\
(5.3-10.6) \\
71.5-80.6 \\
(6.9-12.9) \\
38.9-74.9 \\
(3.8-9.4) \\
64.5-74.2 \\
(3.3-5.6)\end{array}$ & $\begin{array}{l}\text { (You et } \\
\text { al., 2007) }\end{array}$ \\
\hline
\end{tabular}




\begin{tabular}{|c|c|c|c|c|}
\hline Analyte & Matrix & Extraction Procedure: SRM & $\begin{array}{c}\text { \%Recovery } \\
\text { (\% RSD) }\end{array}$ & Ref. \\
\hline & & $\begin{array}{l}\text { rinsed three times with } \mathrm{MeOH} \text {. The mixture was dried } \\
\text { by rotatory evaporator at } 45{ }^{\circ} \mathrm{C} \text { and redissolved in } \\
\text { acetonitrile. } \\
\mathrm{UE} 2 \mathrm{~g} \text { of sample with } 40 \mathrm{~mL} \mathrm{MeOH} \text { were placed into } \\
\text { a } 100 \mathrm{~mL} \text { flask and extracted in a water bath and } \\
\text { sonicated for } 90 \mathrm{~min} \text {. After completing extraction the } \\
\text { extract was filtered and the flask rinsed three times } \\
\text { with MeOH. The mixture was dried by rotatory } \\
\text { evaporator at } 45^{\circ} \mathrm{C} \text { and reconstituted in acetonitrile. } \\
\mathrm{SE} 2 \mathrm{~g} \text { of sample were placed in a glass soxhlet } \\
\text { thimble and } 40 \mathrm{~mL} \mathrm{MeOH} \text { were added in a } 100 \mathrm{~mL} \\
\text { flask, The flask was fitted with water cooling } \\
\text { condenser tube and immersed in a water bath. SE was } \\
\text { carried out for } 2 \mathrm{~h} \text { at } 100{ }^{\circ} \mathrm{C} \text {. After that the extract was } \\
\text { filtered and the sediments were rinsed three times } \\
\text { with MeOH. The mixture was dried by rotatory } \\
\text { evaporator at } 45^{\circ} \mathrm{C} \text { and rsuspeded in acetonitrile. }\end{array}$ & & \\
\hline $\begin{array}{l}13 \text { phenoxy } \\
\text { acids } \\
\text { herbicides }\end{array}$ & Rice & $\begin{array}{l}\text { QuEChERS. } 10 \mathrm{~g} \text { of rice with } 5 \mathrm{~mL} \text { water were } \\
\text { vortexed for } 1 \mathrm{~min} .10 \mathrm{ml} 0.5 \% \text { acetic acid in } \mathrm{MeCN} \\
\text { were added and shaken two times in vortex. } 4 \mathrm{~g} \\
\mathrm{MgSO}_{4}, 1.0 \mathrm{~g} \text { of tri-Na, } 0.5 \mathrm{~g} \text { di-Na citrate and } 1 \mathrm{~g} \text { of } \\
\mathrm{NaCl} \text { were added, vortexed and centrifuged. Clean } \\
\text { up: an aliquot of the extract with } 250 \mathrm{mg} \mathrm{C}-18,100 \mathrm{mg} \\
\text { of alumina neutral and } 1.5 \mathrm{~g} \mathrm{MgSO}_{4} \text {, were shaken and } \\
\text { centrifuged. } 5 \mathrm{~mL} \text { of the solution were concentrated to } \\
\text { dryness and reconstituted for analysis. }\end{array}$ & $\mid \begin{array}{l}45-104 \\
(<13.3)\end{array}$ & $\begin{array}{l}\text { (Koesuk } \\
\text { wiwat et } \\
\text { al., 2008) }\end{array}$ \\
\hline $\begin{array}{l}15 \\
\text { phenylureas } \\
\text { herbicides }\end{array}$ & Rice & $\begin{array}{l}\text { Solvent Extraction/SPE. } 10 \mathrm{~g} \text { of rice were homogenized } \\
\text { with } 50 \mathrm{~mL} \mathrm{MeCN} \text { for } 2 \mathrm{~min} \text {, and filtered into a mixing } \\
\text { cylinder and sealed with a stopper, } 10 \mathrm{~g} \text { of } \mathrm{NaCl} \text { were } \\
\text { added and shaked, and the phases were allowed to } \\
\text { stand for } 20 \mathrm{~min} \text {. A } 25 \mathrm{~mL} \text { portion of the supernatant } \\
\text { was evaporated to dryness, and dissolved in } 2 \mathrm{~mL} \text { - } \\
\text { hexane. Clean up: the extract was transferred to a } \\
\text { Florisil SPE column and eluted with } 5 \mathrm{~mL} \text { acetone:n- } \\
\text { hexane (40:60), then concentrated to dryness and } \\
\text { dissolved in MeCN: water (1:1) for analysis. }\end{array}$ & $\begin{array}{l}75.3-104.3 \\
(1.5-9.6)\end{array}$ & $\begin{array}{l}\text { (Mou et } \\
\text { al., 2008) }\end{array}$ \\
\hline Isoproturon & $\begin{array}{l}\text { Cereal } \\
\text { grains } \\
\text { and } \\
\text { pasta }\end{array}$ & $\begin{array}{l}\text { Solvent Extraction. } 15 \mathrm{~g} \text { of sample with } 4 \mathrm{~mL} \text { of water } \\
\text { and } 30 \mathrm{~mL} \text { acetone were placed in a centrifuged bottle } \\
\text { homogenized using an ultra turrax for } 30 \mathrm{~s} \text { at } 13500 \\
\text { rpm. Then } 30 \mathrm{~mL} \text { hexane and } 30 \mathrm{~mL} \text { dichloromethane } \\
\text { were added to the bottle and homogenized for further } \\
1 \mathrm{~min} \text { at } 13500 \mathrm{rpm} \text {. The matrix and extract were } \\
\text { separated by centrifugation for } 2 \mathrm{~min} \text { and the extract } \\
\text { decanted into a } 200 \mathrm{~mL} \text { volumetric flask. The matrix } \\
\text { was resuspended in } 30 \mathrm{~mL} \text { acetone, } 30 \mathrm{~mL} \\
\text { dichloromethane and } 30 \mathrm{~mL} \text { hexane and extracted } \\
\text { again for } 1 \mathrm{~min} \text {. The } 2 \mathrm{nd} \text { extract was mixed with the } \\
\text { previous one and made up to } 200 \mathrm{~mL} \text { with } \\
\text { dichloromethane. A } 4 \mathrm{~mL} \text { aliquot was transferred into } \\
\text { a borosilicate glass culture tube, } 50 \mu \mathrm{L} \text { of } 50 \%\end{array}$ & $\begin{array}{l}94-100 \\
(0.8-5.8)\end{array}$ & $\mid$\begin{tabular}{ll}
\multicolumn{2}{|l}{ Winrow } \\
et & al., \\
$2003)$ &
\end{tabular} \\
\hline
\end{tabular}




\begin{tabular}{|c|c|c|c|c|}
\hline Analyte & Matrix & Extraction Procedure: SRM & $\begin{array}{c}\% \text { Recovery } \\
\text { (\% RSD) }\end{array}$ & Ref. \\
\hline & & $\begin{array}{l}\text { propylene glycol in acetone was added and the } \\
\text { mixture evaporated under a nitrogen stream. The } \\
\text { residue was reconstituted with } 1 \mathrm{~mL} \text { dichloromethane } \\
\text { and placed onto a SPR cartridge containing } 200 \mathrm{mg} \\
\text { aminopropyl sorbent. The sample tube was rinsed } \\
\text { successively with } 0.5 \mathrm{~mL} \text { dichloromethane and } 2 \mathrm{~mL} \\
\text { dichloromethane/MeOH (99:1). The combined eluates } \\
\text { were evaporated to nearly dryness and the residue } \\
\text { reconstituted in } 1 \mathrm{~mL} \mathrm{MeOH} \text { for analysis. }\end{array}$ & & \\
\hline $\begin{array}{l}\text { Phenoxy } \\
\text { acids } \\
\text { herbicides }\end{array}$ & $\begin{array}{l}\text { Cereals } \\
\text { (plant } \\
\text { samples) }\end{array}$ & $\begin{array}{l}5 \mathrm{~g} \text { of sample were extracted with } 0.1 \mathrm{M} \mathrm{NaOH} \\
(2 \times 25 \mathrm{~mL}) \text { in a sorvall homogenizer, the extract was } \\
\text { filtered and the filter cake washed twice with } 5 \mathrm{~mL} \text { of } \\
\text { the basic aqueous solution. The extract was mixed } \\
\text { with } 25 \mathrm{~mL} \text { saturated sodium chloride solution and } \\
\text { the pH lowered to near } 5 \text { by the addition of } 2 \mathrm{M} \\
\mathrm{H}_{2} \mathrm{SO}_{4} \text {, the solution let stand for } 15 \mathrm{~min} \text { and the liquid } \\
\text { decanted. Then the pH of the solution was lowered } \\
\text { again to } 1 \text { the solution was transferred to a separatory } \\
\text { funnel and extracted with diethyl ether }(2 \times 50 \mathrm{~mL}) \text {. } \\
\text { The organic phase was extracted with } 0.5 \mathrm{M} \mathrm{NaHCO} \\
(2 \times 25 \mathrm{~mL}) \text {, the combined aqueous solution acidified } \\
\text { to pH } 1 \text { by adding carefully } 3 \mathrm{M} \mathrm{H}_{2} \mathrm{SO}_{4}(10 \mathrm{~mL}) \text { and } \\
\text { extracted with } \mathrm{CHCl}_{3}(2 \times 25 \mathrm{~mL}) \text {. The organic phase } \\
\text { was filtered through } \mathrm{Na}_{2} \mathrm{SO}_{4} \text { and solvent concentrated } \\
\text { to dryness under vacuum. }\end{array}$ & $\begin{array}{l}95.5-104.0 \\
(1.4-10.3)\end{array}$ & $\begin{array}{l}\text { (Sánchez- } \\
\text { Brunete } \\
\text { et al., } \\
1994)\end{array}$ \\
\hline $\begin{array}{l}\text { Glyphosate, } \\
\text { Gluphosina } \\
\text { te and their } \\
\text { metabolites }\end{array}$ & $\begin{array}{l}\text { Rice, } \\
\text { soybean }\end{array}$ & $\begin{array}{l}\text { Rice } 5 \mathrm{~g} \text { of milled rice and } 40 \mathrm{~mL} \text { water were sonicated } \\
\text { for } 3 \mathrm{~min} \text {, after resting for } 30 \mathrm{~min} \text { it was centrifuged } \\
\text { for the AG1-X8 anion exchange chromatography. } \\
\text { Soybean } 5 \mathrm{~g} \text { of soybean sprouts with } 25 \mathrm{~mL} \text { water } \\
\text { were mixed in a shaker for } 10 \mathrm{~min} \text {, after resting for } 1 \\
\text { min } 15 \mathrm{~mL} \text { acetone were added and centrifuged for } \\
\text { the AG1-X8 anion exchange chromatography. } \\
30 \mathrm{~mL} \text { of soybean extract or rice extract were applied } \\
\text { onto a preconditioned AG1-X8/ Dowex } 1 \text {-X2 column } \\
\text { which was first washed with } 15 \mathrm{~mL} 40 \% \text { acetone and } \\
\text { eluted by repeated elution with } 15 \mathrm{~mL} \text { of } 0.5 \mathrm{~N} \mathrm{HCl} \\
\text { five times. Each pooled eluate was dried under } \\
\text { reduced pressure at a temperature lower than } 55{ }^{\circ} \mathrm{C} \\
\text { for the derivatization reaction and Florisil clean-up. } \\
\text { Florisil clean-up of the derivatization products: } \\
\text { derivatives in mixed standard solution were dissolved } \\
\text { in } 1 \mathrm{~mL} \text { ethylacetate and applied to a Florisil cartridge } \\
\text { (500 mg, } 6 \mathrm{~mL} \text { previously conditioned with } 5 \mathrm{~mL} \\
\text { ethylacetate. The cartridge was eluted with } 10 \mathrm{~mL} \\
\text { ethylacetate followed by } 10 \mathrm{~mL} \text { of acetone, } 10 \mathrm{~mL} \\
\text { acetone / MeOH (1:1) mixture, } 10 \text { mL acetone } / \\
\text { MeOH (1:2) mixture and } 10 \mathrm{~mL} \text { MeOH. Each pooled } \\
\text { fraction of mix standard solution was dried under } \\
\text { reduced pressure and then dissolved in } 1 \mathrm{~mL} \\
\text { ethylacetate for analysis. }\end{array}$ & $\begin{array}{l}72-119 \\
9.6) \\
86-101 \\
6.5)\end{array}$ & $\begin{array}{l}\text { (Tseng et } \\
\text { al., 2004) }\end{array}$ \\
\hline
\end{tabular}




\begin{tabular}{|c|c|c|c|c|}
\hline Analyte & Matrix & Extraction Procedure: SRM & $\begin{array}{c}\text { \%Recovery } \\
\text { (\% RSD) }\end{array}$ & Ref. \\
\hline $\begin{array}{l}\text { Trazine } \\
\text { herbicides }\end{array}$ & Wheat & $\begin{array}{l}\text { PLE } 7 \mathrm{~g} \text { of sample were mixed with } 4.5 \mathrm{~g} \text { of } \\
\text { hydromatrix and placed in a } 34 \mathrm{~mL} \text { extraction cell and } \\
\text { extracted with dichloromethane/n-hexane (1:4) } \\
\text { solution. The PLE conditions were as follows: pressure } \\
1500 \text { psi, heating time } 5 \mathrm{~min} \text {, purge volume } 60 \% \text {, } \\
\text { purge time } 100 \mathrm{~s} \text {, } 2 \text { static cycles, static time } 6 \text { min. The } \\
\text { total extraction time was } 21 \mathrm{~min} \text {, the extract were } \\
\text { evaporated to dryness in a rotavapor at } 40-50{ }^{\circ} \mathrm{C} \text { and } \\
\text { the dry residue reconstituted with } 5 \mathrm{~mL} \\
\text { dichloromethane/n-hexane/acetone }(1: 1: 1) \text {. The clean- } \\
\text { up was performed using OASIS MCX cartridges } \\
\text { conditioned with } 10 \mathrm{~mL} \text { dichloromethane, once the } \\
\text { retention step has been completed the cartridges were } \\
\text { dried under vacuum for } 10 \text { min. The elution of the } \\
\text { retain compounds was accomplished with } 4 \mathrm{~mL} \text { of } \\
25 \% \text { ammonia solution /MeOH (15:85). The organic } \\
\text { phase was then dried under a stream of nitrogen at } 40- \\
50{ }^{\circ} \mathrm{C} \text { and reconstituted in } 0.5 \mathrm{~mL} \text { of MeOH/water } \\
(1: 1) \text { for analysis. }\end{array}$ & $\begin{array}{l}106-125 \\
(6-18)\end{array}$ & $\begin{array}{ll}\text { (Carabias } \\
\text {-Martínez } \\
\text { et } & \text { al., } \\
2007) & \end{array}$ \\
\hline
\end{tabular}

Table 9. Main methodologies used for the single residue analysis of herbicides in cereals. (Pareja el al unpublished)

Glyphosate is a highly polar herbicide, very soluble in water and insoluble in most organic solvents. For this reason its extraction is generally performed with water or water/chloroform, sometimes at acidic $\mathrm{pH}$, but in this process different components of the matrix are co-extracted thus a clean-up procedure is required (Tadeo et al., 2000).

In Table 9 three different analytical methodologies for the determination of glyphosate in cereals are described. Hogendoorn et al., in 1999 described the rapid determination of glyphosate by means of pre-column derivatization with 9-fluorenylmethyl chloroformate and coupled column liquid chromatography with fluorescence detection. The overall recovery of this herbicide was $86 \%$ with a RSD of $9.5 \%$. This procedure implies the extraction with water followed by a clean-up step in a C-18 bonded silica cartridge. The extract was then subjected to derivatization and analysis (Hogendoorn et al., 1999).

In 2004 Tseng et al., reported the analysis of this herbicide and its metabolites in rice and soybean by extraction with water or acetone followed by a clean-up in an AG1-X8/ Dowex $1-\mathrm{X} 2$ anion exchange column and then a single derivatization with trimethylortoacetate in the presence of HAc. The derivative products were then purified using a Florisil cartridge. The detection of these analytes was made by using a gas chromatograph with flame photometric detector. The recoveries and RSDs were $72 \%$ and $6.5 \%$ for rice and $86 \%$ and 6.5 $\%$ for soybean respectively with a limit of detection of $20 \mu \mathrm{gkg}^{-1}$ (Tseng et al., 2004).

In 2007, Andersen et al., organized an intercomparison study for the determination of glyphosate and other herbicides in wheat. The authors described the procedure used by their laboratory for the analysis of these herbicides as follows; the extraction of the analytes with water and then a clean-up step online on a polystyrene based reverse phase column and separated by ion chromatography-HPLC tandem mass spectrometry. The average recovery was $96 \%$ with a coefficient of variation of $4 \%$ (Andersen et al., 2007). 
The EU-CRL for SRM in Stuttgart used a straightforward methanol extraction at $\mathrm{pH}<2$ of wheat flour to validate a new multi class residue method for traditionally analyzed herbicides and metabolites using SRM like glyphosate, AMPA and gluphosinate and MPPA. This procedure was used to analyze some fruits and vegetables matrices.

Glyphosate shares structural similarities with amino acids and therefore has low UV absorption and fluorescence is low and also presents the disadvantage that vaporizes easily upon heating. Thus, it presents difficulties in the quantification by high performance liquid chromatography (LC-UV), LC fluorescence detection and gas chromatography. The analysis of this herbicide by gas chromatography requires its derivatization, this procedure involves the use of trifluoroacetic anhydride (TFAA) and trifluoroethanol, TFAA and diazomethane or HBFA and 2-choroethanol (Tadeo et al., 2000).

Gas and liquid chromatography with classical detectors.

Gas chromatography is widely used in the analysis of herbicide residues, due to the high selectivity and sensitivity of the detection systems.

The classical detectors most often used are the flame ionization detector (FID), nitrogenphosphorus detector (NPD), Thermo ionic detection, electro capture detection (ECD), but in the last decade MS coupled to GC has been the choice for the analysis of herbicides, especially in MRM methods (Tadeo et al., 2000).

The NPD is employed for herbicides containing nitrogen, such as triazines, dinitroanilines or chloroacetamides, this detection system allows limits of detection in the range of $\mu \mathrm{g}-\mathrm{mg} \mathrm{kg} \mathrm{k}^{-1}$.

In the case of ECD, this detector has high sensitivity for halogenated compounds, although its linear range is narrow. It has been used in the analysis of halogenated phenoxyacids, benzonitriles, dinitroanilines, glyphosate and multiresidue analysis, frequently after derivatization.

Liquid Chromatography (LC) is very useful for polar, thermally labile and low-volatility pesticides which in general cannot be directly analyzed by GC, so LC is preferred instead of the use of derivatization techniques.

Most pesticides, including those not easily analyzed by GC, can also be separated by highperformance liquid chromatography without the need of chemical derivatization. phenylureas, organophosphorus pesticides, triazines, quaternary ammonium compounds and chlorinated phenoxy acids are examples of pesticides submitted to LC analysis (Thurman et al., 2005).

Conventional LC detectors such as the UV detector are, however, not selective enough for pesticide analysis in complex matrices. Moreover, selective detectors such as fluorescence detection can only be applied after derivatization.

GC-MS/MS and LC-MS/MS

Over the last 20 years liquid chromatography-mass spectrometry (LC-MS) techniques have advanced dramatically in their sensitivity, specificity and reliability. Detection of sub-ppt concentrations is becoming routine for many organic analytes and methods achieving detection of a few hundred femtograms of some analytes have been reported. Such progress Is mostly due to the development of hyphenated LC-tandem MS techniques, which are today the methods of choice for the determination of trace organic analytes in food and environmental samples. Such growth in the use of LC-MS/MS for the analysis of organic contaminants in environmental matrices has been compelled by the need for high-quality 
data on their occurrence in the environment at very low concentration levels (Petrovic et al., 2010).

\section{Conclusion}

Herbicides are integrated to the general cropping systems. Routine herbicide application in intensive crop production is performed following a more or less strict calendar but the number of applications can be more frequent if a weed suddenly threatens the culture. The rotational no-tillage based productive system winter crop-summer crop uses many herbicides like atrazine, sulphonylureas and imidazolinones that can accumulate in soils and in a carry-over phenomenon injure the newly planted crop. Herbicides can be found in every environmental compartment but their occurrence in water, soils and crops are of paramount importance from a toxicological point of view. Herbicides that have low Kow and Koc, can be found in water, either ground or surface through run off, leaching or lixiviation. Therefore herbicides can be found not only in the application site as they migrate through water flows. On the other hand, high Koc and / or Kow herbicides remain trapped in soils. Many different analytical methodologies have been developed to determine pesticide residue concentrations. Herbicide residue analysis is not only a valuable tool to evaluate threshold damage limits for the carry over phenomenon but also their residual levels knowledge are fundamental to evaluate the sustainability of the global agroecosystem. The development of chromatographic hyphenated MS/MS techniques allow the broadening of MRMs scope and therefore, lower detections limits with high accuracy have been reached for a high number of pesticides, but the most commonly developed MRM include only few herbicides. The challenges of herbicide residue analysis are the low application dose of the active substances and therefore, sample handling and clean-up procedures are still the bottle neck of the analytical methodologies. Selective clean up procedures have been developed to isolate and concentrate the searched compounds during the last years. In this context, an increasing amount of methods for different food and environmental matrices have been published. New analytical procedures based on selective polymer extraction (MIP, SPME) are interesting possibilities. As general procedure, SPE extraction is the method of choice for water. Nevertheless, for herbicide residue analysis in soil, the type of soil determined the scope and clean up methodology to follow. After the success of the GMO soybean RR glyphosate-resistant variety, the trend for new crop varieties introduction is based on their selective resistance to specific herbicides like imidazolinones or gluphosinate and sulphonylureas. If these herbicides will be applied in no-tillage production systems at the same ratio as glyphosate is nowadays, environmental issues will probably arise, as imidazolinones and sulphonylureas are semi persistent molecules.

\section{References}

Ampong-Nyarko, K. \& De Datta, S.K. (1991) A handbook for weed control in Rice, Manila Philippines.

Anastassiades, M.; Lehotay, S. J.; Štajnbaher, D.; Schenck, F. J. (2003) J. AOAC Int. 86, 412431.

Anderson, R.L.; Barrett, M.R. (1985) J. Environ. Qual. 14, 1, 111-114.

Andersen, J. H.; Bille, R. L.; Granby, K. (2007) Food Add. Contam. 24, 140-148. 
Ayano, E.; Kanazawa, H.; Ando, M.; Nishimura, T. (2004) Anal. Chim. Acta 507, 211-218.

Barchanska, H.; Baranowska, I. (2009) Rev. Environ. Contam. and Toxicol. 200, 53-84.

Bastide, J.; Cambon, J.; Breton, F.; Piletsky, S.; Rouillon, R. (2005) Anal. Chim. Acta 542, 97-103.

Baugros, J.B.; Olive, C.C.; Giroud, B.; Gauvrit, J. Y.; Lanteri, P.; Grenier-Loustalot, M. F.; (2009) J. Chromatogr. A 1216: 4941-4949.

Boivin, A.; Cherrier, R.; Schiavon, M. (2005) Chemosphere 61, 668-676.

Bradford, W.; Minton, M. A.; Matocha, S. A. (2008) Weed Technol. 22, 3, 425-430.

Cacho, C.; Turiel, E.; Perez-Conde, C. (2009) Talanta 78, 1029-1035.

Carabias-Martínez, R.; García-Hermida, C.; Rodríguez-Gonzalo, E.; Soriano-Bravo, F. E.; Hernández-Méndez. J. (2003) J. Chromatogr. A 1002, 1-12.

Carabias-Martínez, R.; Rodríguez-Gonzalo, R.; Fernández-Laespada, E.; Calvo-Seroner, L.; Sánchez San Roman, F. J. (2003) Water Research 37, 928-938.

Carabias-Martínez, R.; Rodríguez-Gonzalo, E.; Herrero-Hernández, E.; Hernández-Méndez, J. (2004) Anal. Chim. Acta 517, 71-79.

Caseley, J.J. (1996) Serie de Estudios FAO: Producción y protección vegetal -Manejo de Herbicidas para países en desarrollo, Montevideo, Uruguay.

Cepeda, S.; Rossi, A. R.; Ponsa, J. (1995) Tolerancia o resistencia de malezas a los herbicidas, In: Carpeta de Producción Vegetal, Tomo XIII. Generalidades, Información, N.125, 5p. EEA Pergamino.

Cervera, M.I.; Medina, C.; Portolés, T.; Pitarch, E.; Beltrán, J.; Serrahima, E.; Pineda, L.; Muñoz, G.; Centrich, F.; Hernández, F. (2010) Anal. Bioanal. Chem. 397, 7, 2873-2891.

Chebatarrof N. (2007) Conexión Tecnológica 202, 1-6.

Crespo-Corral, E.; Santos-Delgado, M. J.; Polo-Díez, L. M.; Soria, A. C. (2008) J. Chromatogr. A 1209, 22-28.

Cserháti, T. (2004) Biomed. Chromatogr. 18, 350-359.

Degenhardt, D.; Cessna, A.J.; Raina, R.; Pennock, D.J.; Farenhorst, A. (2010) J. Environ. Sci. Heal. $B$ 45, 1, 11-24.

Díez, C.; Barrado, E.; Marinero, P.; Sanz, M. (2008) J. Chromatogr A 1180, 10-23

Díez, C.; Barrado, E. (2010) Anal. Bioanal. Chem. 397, 1617-1626.

Díez, C.; Traag, W. A.; Zommer, P.; Marinero, P.; Atienza, J. (2006) J. Chromatogr. A 1131, 11-23.

Djozan, D.; Ebrahimi, B. (2008) Anal. Chim. Acta 616, 2, 2, 152-159

García-Reyes, J.F.; Jackson, A.U.; Molina-Díaz, A.; Cooks, R.G. (2009) Anal. Chem. 81, 2, 820829.

García Valcarcel, A.I.; Tadeo, J.L. (1999) J. Agric. Food Chem. 47, 3895-3900.

García-Valcarcel, A. I.; Tadeo, J. L. (2009) Anal. Chim. Acta 641, 117-126.

Geiss, S.; Gebert, S. (2006) Acta Hydrochim. Hydrobiol. 34, 464.

Genta, H.; Villamil, J. (1992) Serie Técnica INIA ISBN: 9974-556-26-0,141, Montevideo, Uruguay

Granby, K.; Johannesen, S.; Vahl, M. (2003) Food Add. Contam. 20, 8, 692-698

Haouari, J.; Dahchour, A.; Peña-Heras, A.; Louchard, X.; Lennartz, B.; Alaoui, M.E.; Satrallah A. (2006) J. Environ. Sci. Heal. B 41, 6, 883-893.

Harri, L. (1994) Manual de identificação e controle de plantas danhinas: plantio direto e convencional, 6 ed. Nova Odessa, SP (Brazil). Editora Plantarum.

He, Y.; Xu, J.; Wang, H.; Zhang, Q.; Muhammad, A. (2006) Chemosphere 65, 497-505. 
Herrmann, S.S; Christensen, H.B.; Poulsen, M. E. (2006) Technical report for Cereals, National Food Institue, the Danish Technical University. CRL for Cereals and Feeding Stuff.

Hill, B.D.; Harker, K.N.; Hasselback, P.; Moyer, J.R.; Inaba, D.J.; Byers, S.D. (2002) Can. J. Plant Sci. 82, 2, 481-484.

Hogendoorn, E. A.; Ossendrijver, F. M.; Dijkman, E.; Baumann, R. A. (1999) J. Cromatogr. A $833,67-73$.

Howatt, K.A.; Endres, G.J. (2006) Weed Technol. 20, 1, 67-73. http://www.crlpesticides.eu/docs/public/tmplt_article.asp?CntID=748\&LabID=2 $00 \&$ Lang $=\mathrm{EN}$

http://www.casafe.org/estad/m2009.htm

Itoh, N.; Otake, Y.; Aoyagi, Y.; Matsuo, M.; Yarita, T. (2009) Chromatographia 70, 1073-1078.

Jeannot, R.; Sabik, H.; Sauvard, E.; Genin, E. (2000) J. Chromatogr. A 879, 51-71.

Kaihara, A.; Yoshii, K.; Tsumura, Y.; Ishimitsu, S.; Tonogai, Y. (2002) J. Health Sci. 48, 173178.

Klein, J. \& Alder, L. (2003) J. AOAC Int. 86, 1015-1036.

Koesukwiwat, U.; Sanguankaew, K.; Leepipatpiboon, N. (2008) Anal. Chim. Acta 626, 10-20.

Kumar, A.; Malik, A.K.; Picó, Y. (2010) Electrophoresis 31,13, 2115-2125.

Kuster, M.; López de Alda, M. J.; Barata, C.; Raldua, D.; Barceló, D. (2007) Talanta 75, 390401.

Lambropoulou, D. A. \& Albanis, T. A. (2007) Anal. Bioanal. Chem. 389, 1663-1683.

Lee, S. J.; Park, H. J.; Kim, W.; Jin, J. S.; El-Aty, A.M.A.; Shim, J. H.; Shin, S. C. (2009) Biomed. Chromatogr. 23, 434-442.

Lehotay, S. J.; Maštovská, K.; Lightfield, A. R. (2005) J. AOAC Int. 88, 615-629.

Lesueur, C.; Gartner, M.; Mentler, A.; Fuerhacker, M. (2008) Talanta 75, 284-293.

Libin, L.; Hashi, Y.; Yaping, Q.; Haixia, Z.; Jinming, L. Chin. (2006) J. Anal. Chem. 34, 783-786.

Lieqing, Y.; Xiaomin, Z.; Jie Z. (2010) Anal. Chim. Acta 670, 72-77.

Liu, L. B.; Hashi, Y.; Qin, Y. P.; Zhou, H. X.; Lin, J. M. (2007) J. Chromatogr. B 845, 61-68.

Lucini, L. \& Molinari, G. P. (2010) Pest Manag. Sci. 66, 621-626.

Hirahara, Y.; Kimura, M.; Inoue, T.; Uchikaea, S.; Otani, S.; Haganuma, A.; Matsumoto, N.; Hirata, A.; Maruyama, S.; Iizuka, T.; Ukyo, M.; Ota, M.; Hirose, H.; Suzuki, S.; Uchida, Y. (2005) J. Health Sci. 51, 617-627.

Ma, W. T.; Fu, K. K.; Cai, Z.; Jiang, G. B. (2003) Chemosphere 52, 1627-1632.

Marchesan, E.; Sarzi S.; de Avila G.M.; Machado,L.A.; Zanella, R.; Primel, E.G.; Mussoi Macedo, V.R.; Marchezan, M.G. (2010) Ciencia Rural 40, 5,1053-1059.

Marchese, S.; Perret, D.; Bafile, E.; Gentili, A.; Caretti, F.; Berardino, M. (2009) Cromatographia 70, 761-767.

Marín, J.M.; Gracia-Lor,E.; Sancho,J.M.; López,F.J:; Hernández, F. (2009) J. Chromatogr. A $1216,1410-1420$.

Mazzella, N.; Delmas, F.; Delest, B.; Méchin, B.; Madigou, C.; Allenou, J. P.; Gabellec, R.; Caquet, T. (2009) J. Environ. Monit. 11, 108-115.

Merini, L. J.; Cuadrado, V.; Giuliette, A. M. (2008) Chemosphere 71, 11, 2168-2172

MGAP/Servicios Agrícolas, in http://www.mgap.gub.uy/dgssaa/last accessed July 2010.

Mol, H. G. J.; Bolaños, P.; Zomer, P.; de Rijk, T. C.; Stolker, A.A.M.; Mulder, P. P. J. (2008) Anal. Chem. 80, 9450-9459.

Molina, F.; Cantou, G.; Roel, A. (2010) last accessed August 2010 
<http://www.inia.org.uy/estaciones/ttres/actividades/2010/Resumen 2009_10.pdf>.

Mou, R. X.; Chen, M.; Zhi, J. (2008) J. Chromatogr. B 875, 437-443.

Mullen, A.K.;,Clench, M.R.; Crosland, S.; Sharples, K.R. (2005) Rapid Communications in Mass Spectrometry 19, 18, 2507-2516.

Nanita, S.C.; Pentz, A.M.; Bramble, F.Q. (2009) Anal. Chem. 81, 8, 3134-3142.

Nelson, M.A.; Gates, A.; Dodlinger, M.; Hage, D.S. (2004) Anal. Chem. 76, 805-813.

Nguyen, T. D.; Han, E. M.; Seo, M. S.; Kim, S. R.; Yun, M. Y.; Lee, D. M.; Lee, G. H. (2008) Anal. Chim. Acta 619, 67-74.

Nguyen, T. D.; Lee, B. S.; Lee, B. R.; Lee, D. M.; Lee, G. (2007) Rapid Commun. Mass Spectrom. 21, 3115-3122.

Niell, S.; Pareja, L.; Geis Asteggiante, L.; Cesio, M. V.; Heinzen, H. (2010) Food Add. Contam. A 27, 206-211.

Oppenhuizen, M.E.; Cowell, J.E. (1991) J AOAC Int 74, 2, 317-323.

Ouyang, X.; Zhang, W.; Chang, N, Pan, C.; Zhang, J.; Niu, W. (2009) J. Anal. Chem. 64, 935940.

Pang, G. F.; Liu, Y. M.; Fan, C. L.; Zhang, J. J.; Cao, Y. Z.; Li, X. M., Li, Z. Y.; Wu, Y. P.; Guo, T. T. (2006) Anal. Bioanal. Chem. 384, 1366-1408.

Pareja,L.; Cesio,V.; Heinzen, H.; Fernandez-Alba, A.; (2009) LAPRW , 128.

Patsias,J.; Papadakis,N.E:; Papadopoulou-Mourkidou, E. (2002) J. Chromatogr. A 959, 153161.

Pengyan, L.; Qingxue, L.; Yusong, M.; Jinwei, L.; Xuan, J. Chin. (2006) J. Chromatogr. 24, 228234.

Pizzutti, I. R.; de Kok, A.; Zanella, R., Adaime, M. B.; Hiemstra, M.; Wickert, C.; Prestes, O. D. (2007) J. Chromatogr. A 1142, 123-136.

Petrovic, M.; Farré, M.; López de Alda, M.; Pérez, S.; Postigo, C.; Köck, M.; Radjenovic, J.; Gros, M.; Barceló, D. (2010) J. Chromatogr. A 1217, 4004-4017.

Pinxteren, M. V.; Bauer, C.; Popp, P. (2009) J. Chromatogr. A 1216, 5800-5806.

Polati, S.; Bottaro, M.; Frascarolo, P.; Goseti, F.; Gianotti, V.; Gennaro, M. C. (2006) Anal. Chim. Acta 579, 146-151.

Poulsen, M. E.; Christensen, H. B.; Herrmann, S. S. (2009) Accred. Qual. Assur. 14, 477-485.

Ramezani, M.; Simpson,N.; Oliver,D.; Kookana,R.; Gill,G.; (2009) J. Chromatogr. A 1216, 5092-5100.

Roehrs, R.; Zanella, R.; Pizzuti, I.; Adaime, M. B.; Pareja, L.; Niell, S.; Cesio, M. V.; Heinzen, H. (2009) J AOAC Int. 92, 4, 1191-1195.

Rodríguez-Gonzalo, E.; Carabias-Martínez, R.; Cruz, E.M.; Domínguez-Álvarez, J.; Hernández-Méndez, J. (2009) J Sep. Sci. 32, 4, 575-584.

Rossi, A. R.; Ponsa, J.; Cepeda, S. (1996) Maíz: las malezas, su manejo y control, In: Publicación Miscelánea, N.77, cap.5. EEA Rafaela.

Pareja, L, Cesio, M.V., Heinzen, H., Fernández-Alba A.R. (2010)unpublished results

Sánchez-Brunete, C.; Martínez, L.; Tadeo, J. (1994) J Agric Food Chem 42, 2210-2214.

Schoeneberger, P.J.; Wysocki, D.A.; Benham, E.C.; Broderson, W.D. (1998) Field book for describing and sampling soils. Natural Resources Conservation Service, USDA, National Soil Survey Center, Lincoln, NE.

Schreck,E.; Geret,F.; Gontier,L.; Treilhou, M. (2008) Talanta 77, 298-303.

Serodio, P.; Nogueira, J. M. (2004) Anal. Chim. Acta 517, 147-153. 
Smith, R. J. (1968) Weed Science, 16, 2, 252-255

Smith, S.; Cooper, C.M.; Lizotte, R.E. (2007) Int. J. Ecol. Environ. Sci. 33, 4, 223-231.

Tadeo, J. L.; Sánchez-Brunette, C.; García-Valcárcel, A. I.; Martínez, L.; Pérez, R. A. (1996) J. Chromatogr. A 754, 347-365.

Tadeo, J. L.; Sánchez-Brunette, C.; Pérez, R. A.; Fernández, M. D. (2000) J. Chromatogr. A 882, 175-191.

Takatori, S.; Okihashi, M.; Okamoto, Y.; Kitagawa, Y.; Kakimoto, S.; Murata, H.; Sumimoto, T.; Tanaka, Y. (2008) J AOAC Int. 91, 871-883.

Tan, S.; Evans, R.R.; Dahmer, M.L.; Singh, B.K.; Shaner, D.L. (2005) Pest Manag. Sci. 61, 3, 246-257.

Thurman, E. M.; Ferrer I.; Fernández-Alba A.R. (2005) Chapter 8 LC-MS. I: Basic principles and technical aspects of LC-MS for pesticide analysis, In: Chromatographic-Mass Spectrometric Food Analysis for Trace Determination of Pesticide Residues in series Comprehensive Analytical Chemistry, Fernández-Alba A. R. (Ed.), 369-401, Elsevier B.V., ISBN 13: 978-0-444-50943-7

Tomlin, C. (1996) The Pesticide Manual, 14th Ed. British Crop Protection Council, Farnahan, UK.

Tseng, S. H.; Lo, Y. W.; Chang, P. C.; Chou, S. S.; Chang, H. M. (2004) J. Agric. Food Chem. 52, 4057-4063.

Turiel, E.; Martín, A. (2010) Anal. Chim. Acta 668, 87-99.

Vryzas, Z.; Tsaboula, A.; Papadopoulou-Mourkidou, E. (2007) J. Sep. Sci. 30, 15, 2529-2538.

Vryzas, Z. \& Papadopoulou-Mourkidou, E. (2002) J. Agric. Food Chem. 50, 18, 5026-5033.

Wang, Y.; You, J.; Ru, R.; Ciao, Y.; Gao, S.; Zhang, Y.; You, A. (2010) J Chromatogr A 1217, 26, 4241-4246.

Walorckyk, S. (2007) J. Chromatogr. A 1165, 200-212.

Walorckyk, S. (2008) J. Chromatogr. A 1208, 202-214.

Wells, M. J. M.; Yu, L. Z. (2000) J. Chromatogr. A 885, 237-250.

Winrow, S.; Hird, S.; Brown, P. (2003) Food Add. Contam. 20, 1064-1071.

Woudneh, M.B.; Ou, Z.; Sekela, M.; Tuominen, T.; Gledhill, M. (2009) J. Environ. Qual. 38, 3, 948-954.

Wood, A.; In: Alan Wood's Web Site last accessed august 2010, http://www.alanwood.net/pesticides/class_herbicides.html

Wu, Q.; Wang, C.; Liu, Z.; Wu, C.; Zeng, X.; Wen, J.; Wang, Z. (2009) J. Chromatogr. A 1216, 5504-5510.

Xie, C.; Gao, S.; Zhou, H.K.; Li, H.F. (2010) Luminescence Jul 13. [Epub ahead of print]

Ying, W.; Jingyan, Y.; Ruibing, R.; Yao, X.; Shiqian, G.; Hanqi, Z.; Aimin; Y. (2010) J. Chromatogr. A 1217, 4241-4246.

You, J.; Zhang, H. Zhang, H.; Yu, A.; Xiao, T.; Wang, Y.; Song, D. (2007) J. Chromatogr. B 856, 278-284.

Yu, Z.G.; Ding, W.M.; Chen, Y.H.; You, J.; Liu, Y.Y.; Wang, H.; Yang, Z.D. (2010) Chromatographia 72, 1-2, 33-38.

Zanella, R.; Primel, E. G.; Gonçalves, F. F.; Kurz, M. H. S.; Mistura, C. M. (2003) J. Sep. Sci. 26, 935-938.

Zhang, W. G.; Chu, X. G.; Cai, H. X.; An, J.; Li, C. J. (2006) Rapid Commun. Mass Spectrom. 20, 609-617.

Zhang, Z.; Yang, G.; Zheng, Z.; Chen, Y. (2009) Cromatographia 69, 615-619. 


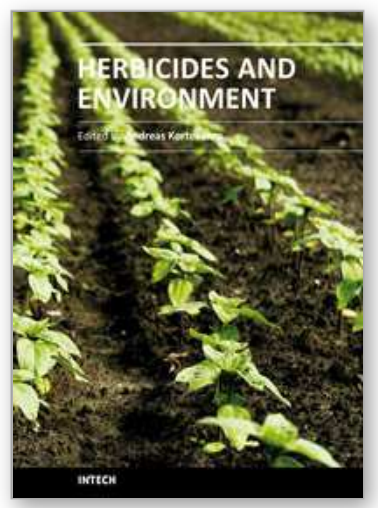

\author{
Herbicides and Environment \\ Edited by Dr Andreas Kortekamp
}

ISBN 978-953-307-476-4

Hard cover, 746 pages

Publisher InTech

Published online 08, January, 2011

Published in print edition January, 2011

Herbicides are much more than just weed killers. They may exhibit beneficial or adverse effects on other organisms. Given their toxicological, environmental but also agricultural relevance, herbicides are an interesting field of activity not only for scientists working in the field of agriculture. It seems that the investigation of herbicide-induced effects on weeds, crop plants, ecosystems, microorganisms, and higher organism requires a multidisciplinary approach. Some important aspects regarding the multisided impacts of herbicides on the living world are highlighted in this book. I am sure that the readers will find a lot of helpful information, even if they are only slightly interested in the topic.

\title{
How to reference
}

In order to correctly reference this scholarly work, feel free to copy and paste the following:

Veronica Cesio, Silvina Niell, Lucia Pareja, Grisel Fernandez, Lucia Geis Asteggiante, Bernardo Bocking, Claudio García, Amadeo R.fernandez-alba and Horacio Heinzen (2011). Critical Revision and Development Perspectives of Herbicide Residues Analysis in Agro Ecosystems, Herbicides and Environment, Dr Andreas Kortekamp (Ed.), ISBN: 978-953-307-476-4, InTech, Available from:

http://www.intechopen.com/books/herbicides-and-environment/critical-revision-and-development-perspectivesof-herbicide-residues-analysis-in-agro-ecosystems

\section{INTECH}

open science | open minds

\author{
InTech Europe \\ University Campus STeP Ri \\ Slavka Krautzeka 83/A \\ 51000 Rijeka, Croatia \\ Phone: +385 (51) 770447 \\ Fax: +385 (51) 686166 \\ www.intechopen.com
}

\author{
InTech China \\ Unit 405, Office Block, Hotel Equatorial Shanghai \\ No.65, Yan An Road (West), Shanghai, 200040, China \\ 中国上海市延安西路65号上海国际贵都大饭店办公楼405单元 \\ Phone: +86-21-62489820 \\ Fax: $+86-21-62489821$
}


(C) 2011 The Author(s). Licensee IntechOpen. This chapter is distributed under the terms of the Creative Commons Attribution-NonCommercialShareAlike-3.0 License, which permits use, distribution and reproduction for non-commercial purposes, provided the original is properly cited and derivative works building on this content are distributed under the same license. 